\title{
HADAR HALLSTRÖM ON PREVENTION AND TREATMENT OF PERI-IMPLANT INFLAMMATION
}
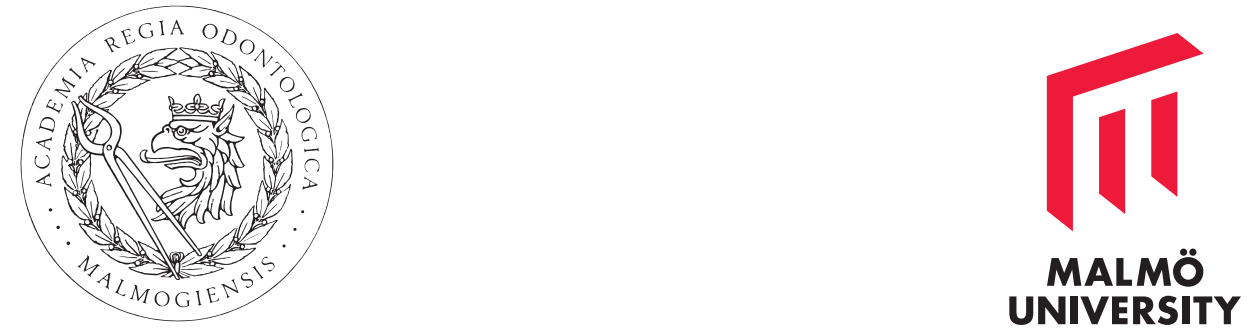

ON PREVENTION AND TREATMENT OF PERI-IMPLANT INFLAMMATION 
Malmö University, Faculty of Odontology Doctoral Dissertation 2018

(C) Copyright Hadar Hallström 2018

ISBN 978-9I-7I04-904-9 (print)

ISBN 978-9I-7I04-905-6 (pdf)

Holmbergs, Malmö 2018 


\section{HADAR HALLSTRO̊M \\ ON PREVENTION AND TREATMENT OF PERI-IMPLANT INFLAMMATION}

Malmö University, 2018

Faculty of Odontology Department of Periodontology 
This publication is available in electronic format at: https://muep.mau.se/ 
To Eva, Cecilia, Johanna, Viktor 



\section{CONTENTS}

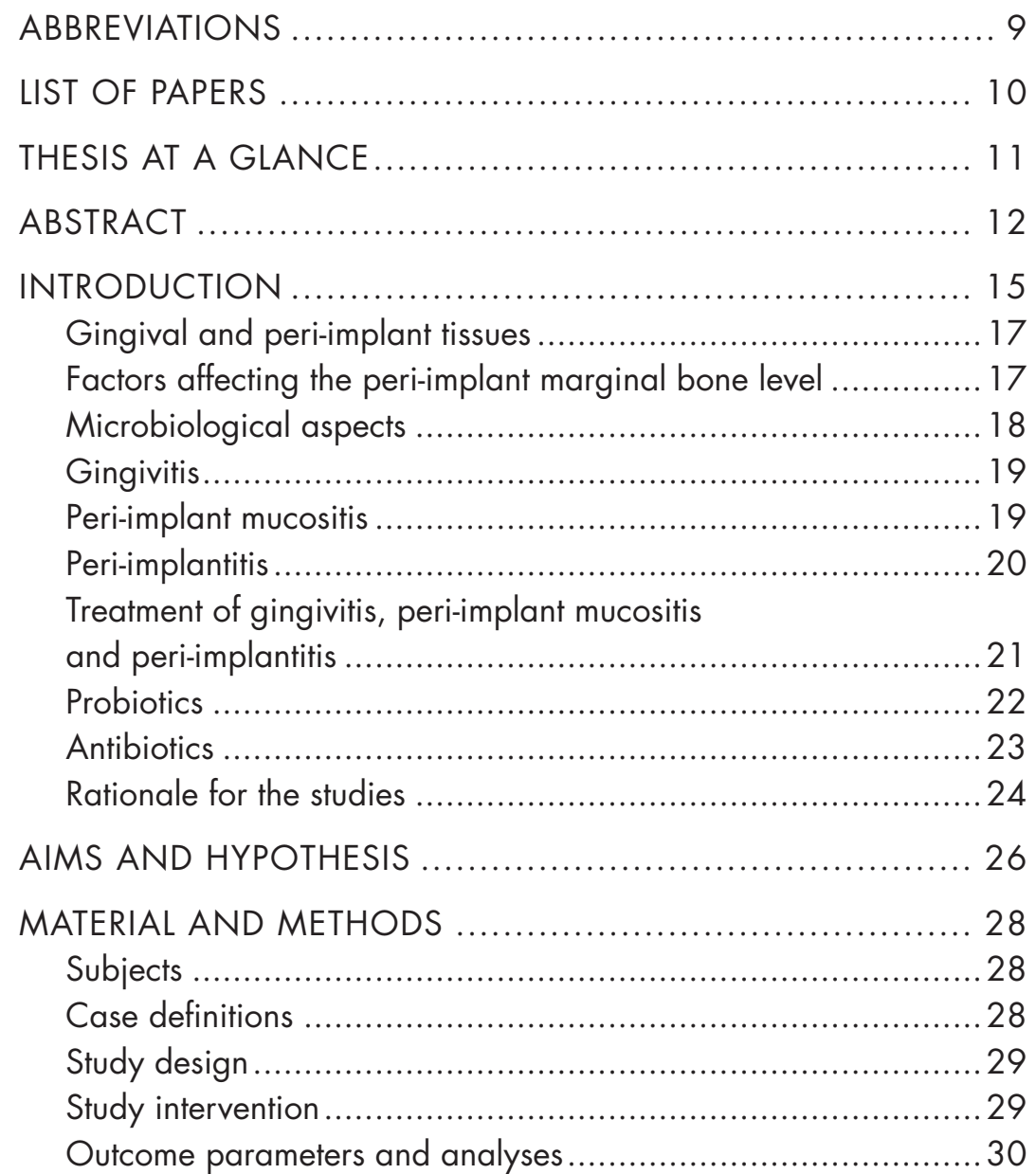


RESULTS .................................................. 33

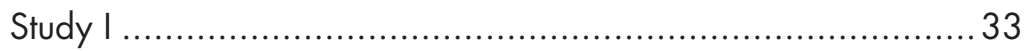

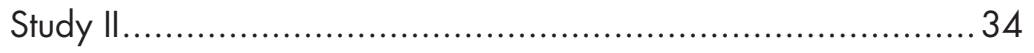

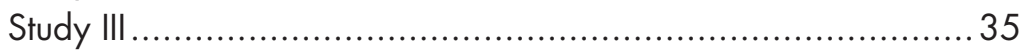

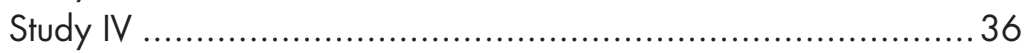

DISCUSSION................................................. 38

CONCLUSIONS ............................................ 48

FUTURE RESEARCH...................................... 49

CLINICAL RECOMMENDATIONS ............................. 50

POPULÄRVETENSKAPLIG SAMMANFATTNING .............. 51

ACKNOWLEDGEMENTS .................................... 54

REFERENCES ............................................. 56

PAPERS I-IV ............................................. 71 


\section{ABBREVIATIONS}

\begin{tabular}{|c|c|}
\hline BOP & Bleeding On Probing \\
\hline CI & Confidence Interval \\
\hline DNA & Deoxyribonucleic acid \\
\hline FAO & $\begin{array}{l}\text { Food and Agriculture Organization of the United } \\
\text { Nations }\end{array}$ \\
\hline GCF & Gingival Crevicular Fluid \\
\hline GI & Gingival Index \\
\hline PPD & Probing Pocket Depth \\
\hline $\mathrm{OHI}$ & Oral Hygiene Instruction \\
\hline $\mathrm{Pi}$ & Peri-implantitis \\
\hline PI & Plaque Index \\
\hline PiM & Peri-implant Mucositis \\
\hline PISF & Peri Implant Sulcular Fluid \\
\hline RCT & Randomized Clinical Trial \\
\hline SD & Standard Deviaation \\
\hline WHO & World Health Organization \\
\hline
\end{tabular}




\section{LIST OF PAPERS}

This thesis is based on the following papers, which will be referred to by their roman numerals as listed below.

I. Hallström H, Lindgren S, Yucel-Lindberg T, Dahlén G, Renvert S, Twetman S. Effect of probiotic lozenges on inflammatory reactions and oral biofilm during experimental gingivitis. Acta Odontol Scand. 2013; 71: 828-833.

II. Hallström H, Lindgren S, Widén C, Renvert S, Twetman S. Probiotic supplements and debridement of peri-implant mucositis: A randomized controlled trial. Acta Odontol Scand. 2016; 74: 60-66.

III. Hallström H, Persson GR, Lindgren S, Olofsson M, Renvert S. Systemic antibiotics and debridement of peri-implant mucositis. A randomized clinical trial. J Clin Periodontol. 2012; 39: 574-581.

IV. Hallström H, Persson GR, Lindgren S, Renvert S. Open flap debridement of peri-implantitis with or without adjunctive systemic antibiotics: A randomized clinical trial. J Clin Periodontol. 2017; 44: 1285-1293. 


\begin{tabular}{|c|c|c|c|c|}
\hline & 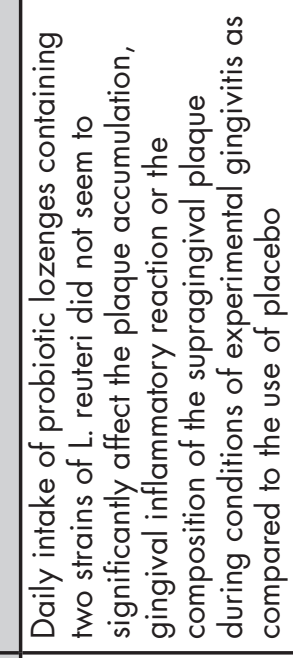 & 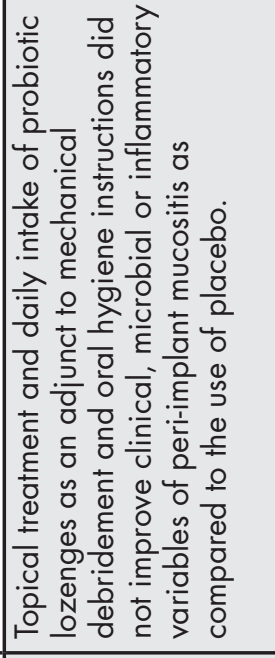 & 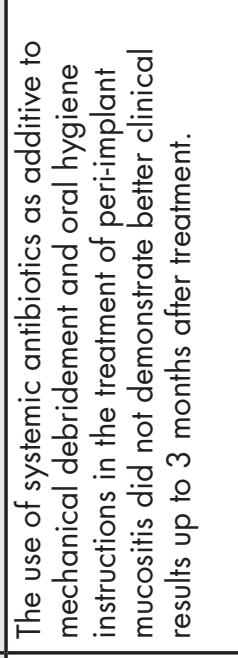 & 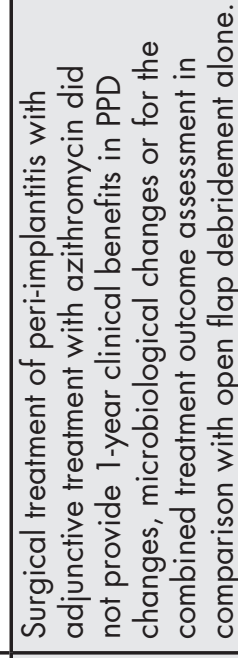 \\
\hline \multicolumn{2}{|c|}{ 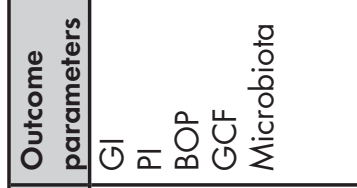 } & 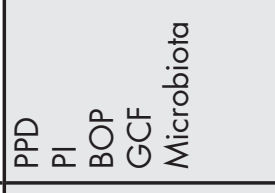 & 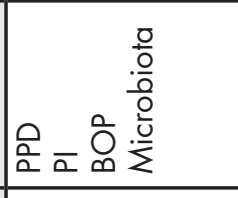 & 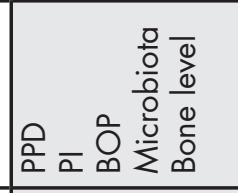 \\
\hline & \begin{tabular}{r}
$\frac{\mathscr{b}}{0}$ \\
\hdashline \\
\hdashline \\
\end{tabular} & 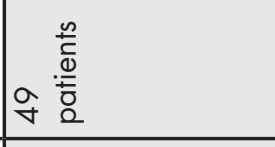 & 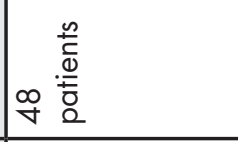 & 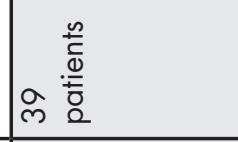 \\
\hline \multicolumn{2}{|c|}{ 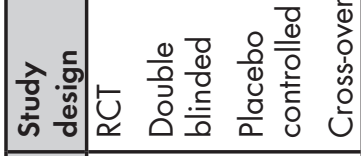 } & 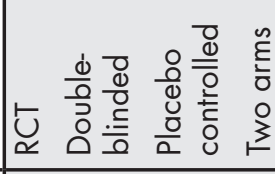 & 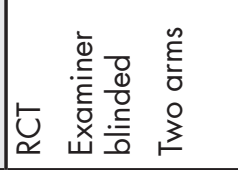 & 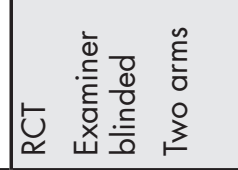 \\
\hline & 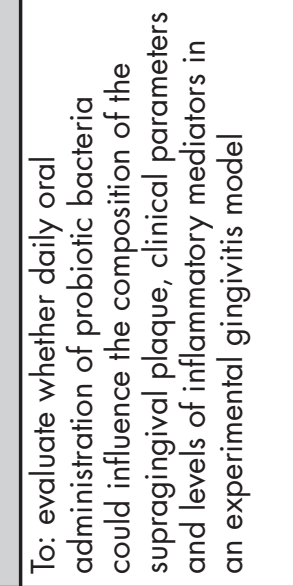 & 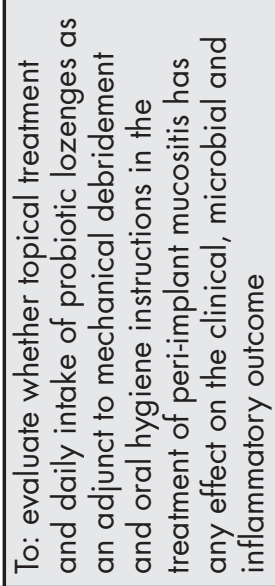 & 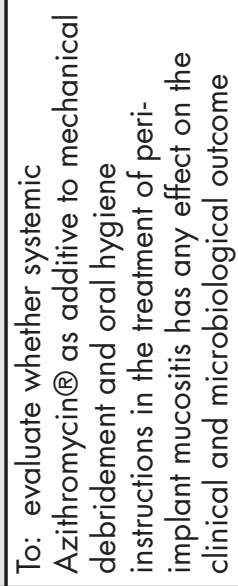 & 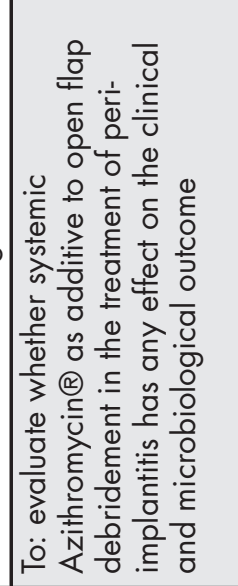 \\
\hline & - & $=$ & $\equiv$ & $\geq$ \\
\hline
\end{tabular}




\section{ABSTRACT}

This thesis focuses on prevention and treatment of biological complications around dental implants.

\section{Background}

An increasing number of individuals have restorations that are anchored to the jaws by dental implants. Modern-day implants are a Swedish invention that became available to patients in the 1970s. Implant restorations are common and several patients have had their implants for more than twenty years. The long-time survival rate is good, but as with all treatments, complications do occur. These complications can be technical problems, like fractures of the framework, discolouring and wear of the prosthesis, or fractures of the actual implant. Biological complications appear initially as peri-implant mucositis (PiM) which is a bacterially induced inflammation of the soft tissue around an implant. PiM may progress into peri-implantitis ( $\mathrm{Pi}$ ) that involves the implant supporting bone and can ultimately lead to loss of the implant. The prevalence of complications has been debated. Depending on patient population and definition used, the prevalence has been reported in the range of $19-65 \%$ for PiM and $1-47 \%$ for Pi.

Treatment of peri-implant diseases consists of reinforcement of the patients' oral hygiene, non-surgical mechanical therapy and in cases with bone loss adjacent to the implant surgical interventions may be needed. Irrespective of treatment method complete resolution of the diseases is rare and even though no evidence exists that 
the use of antibiotics improves the treatment outcome antibiotics are often prescribed. Frequent use of antibiotics is a main contributor to the development of bacterial resistance that has developed into a serious global problem. Probiotics are live bacteria that in adequate doses are beneficial to the host and under certain circumstances have demonstrated abilities to hamper inflammations.

\section{Aims}

The aim of the thesis was to clarify whether 1) probiotics administered in lozenges can prevent or lower the inflammatory reaction to plaque accumulation, 2) if the use of probiotics as an adjunct to mechanical treatment of peri-implant mucositis has a beneficiary effect, and 3) if systemically administered antibiotics given as additive enhance the outcome following the treatment of peri-implant mucositis and peri-implantitis.

\section{Methods}

Four studies were designed to fulfil the aim:

- a placebo controlled cross-over study testing whether probiotics can prevent or lower the inflammatory response to a bacterial challenge.

- a placebo controlled RCT study evaluating whether probiotics given as an additive to mechanical treatment of peri-implant mucositis provides any benefits.

- a RCT study evaluating whether systemically administered antibiotics given as an additive to mechanical treatment of periimplant mucositis are beneficial.

- a RCT study evaluating whether systemically administered antibiotics given as an additive to surgical treatment of periimplantitis are beneficial.

Clinical, microbiological, and immunological parameters were used to analyse study outcomes. 


\section{Results}

- Daily probiotic lozenges had no significant effect on the inflammatory response in an experimental gingivitis model compared to placebo.

- Daily probiotic lozenges as additive to oral hygiene instructions and mechanical debridement had no significant effect on the clinical, microbiological, or immunological outcome in the treatment of peri-implant mucositis compared to placebo.

- Systemically administered antibiotics as additive to oral hygiene instructions and mechanical debridement had no significant effect on the clinical or microbiological outcome in the treatment of peri-implant mucositis.

- Systemically administered antibiotics as additive to oral hygiene instructions and surgical mechanical debridement had no significant effect on the clinical or microbiological outcome in the treatment of peri-implantitis.

\section{Conclusions}

Neither probiotics containing Lactobacillus reuteri or Azithromycin have any major effect on the treatment outcome of periimplant mucositis or peri-implantitis when given as additive to conventional treatment. The use of daily lozenges containing Lactobacillus reuteri yields no benefits when it comes to preventing gingivitis under experimental gingivitis conditions. 


\section{INTRODUCTION}

During the last decades, dental implants have become a frequently used method to replace missing teeth. Rehabilitation of partial and total edentulism with a fixed prosthesis attached to osseointegrated implants has been reported to have a long-term survival rate of 94.8-99.7\% (Iniesta et al., 2012, van Velzen et al., 2015, Hjalmarsson et al., 2016, Park et al., 2017). Biological complications (peri-implant mucositis and peri-implantitis) are common findings usually occurring 5 to 10 years after the installation of dental implants (Mombelli et al., 2012). Peri-implant mucositis has been defined as a reversible inflammatory process with bleeding on gentle probing without signs of loss of supporting bone following the initial bone remodelling during the healing process. Periimplantitis is an inflammatory disease adjacent to a dental implant and a condition with evidence of bleeding on gentle probing and with progressive loss of supporting alveolar bone beyond the biologic bone remodelling process following the initial healing phase (Zitzmann and Berglundh, 2008, Anonymous, 2013).

The reported prevalence of peri-implant diseases varies considerably. In a recent systematic review, the patient based prevalence of peri-implant mucositis and peri-implantitis were reported to be in the range of $19-65 \%$ and $1-47 \%$ respectively (Derks and Tomasi, 2015). The wide range in the reported prevalence may partly be explained by differences in study cohorts, follow-up time and case definitions. Implant removal and surgical procedures to handle biological complications at implants are an increasing clinical problem in patients supplied with dental implants resulting in an economic 
burden on both society and the individual, and negatively affecting the patients' quality of life. Between 2009 and 2014 an increasing number of surgical interventions (operations and extractions) due to peri-implantitis was reported to the Swedish Social Insurance Agency (SSIA, Försäkringskassan) and at the same time the quota of implant extractions increased and 2014 comprised $28 \%$ of performed treatments (Sjödin, 2015). (Figure 1)

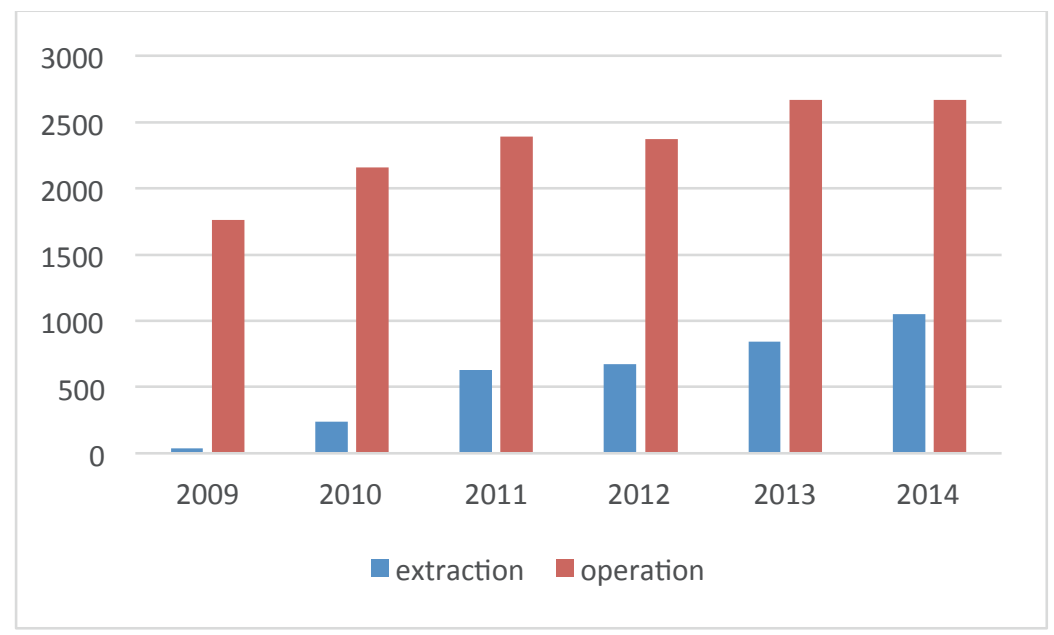

Figure 1. Number of implant extractions and operations due to peri-implantitis reported to the Swedish National Dental Insurance System during 2009-14. 


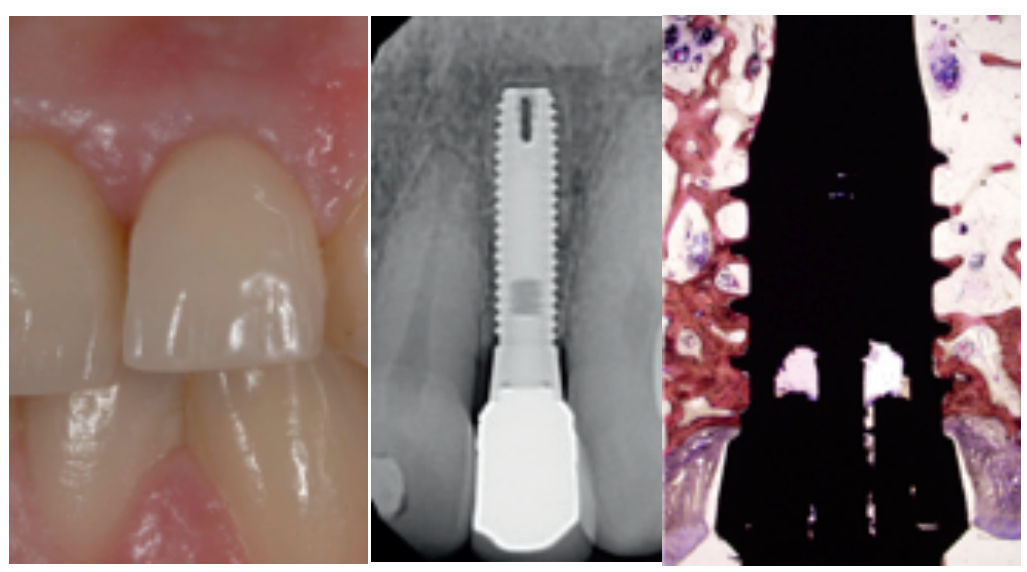

Figure 2. Clinic, radiographic and histologic illustrations of successful implants.

\section{Gingival and peri-implant tissues}

The soft tissue barrier around implants resembles clinically and histologically the gingiva around teeth (Figure 2). Clinically, if placed in keratinised tissue, it has a firm consistence, is pink in colour and has a keratinised zone separated from the non-keratinised alveolar mucosa by a groove below the mucosal margin (Berglundh et al., 1991). Histologically, the tissue facing the implant has a shallow sulcus, a non-keratinised junctional epithelium of 1.5-2.0 $\mathrm{mm}$ and supra crestal 1.0-1.5 $\mathrm{mm}$ of connective tissue. There are collagen fibres originating from the periosteum and organised parallel with the implant (abutment) surface (Berglundh et al., 1991, Berglundh and Lindhe, 1996). The overall distance, bone to soft tissue margin is larger at implants than at teeth (Berglundh et al., 1991, Buser et al., 1992, Abrahamsson et al., 1996, Berglundh and Lindhe, 1996).

\section{Factors affecting the peri-implant marginal bone level}

Using bone level implants with an abutment to pass through the mucosa results in a gap between the two parts close to the marginal bone level. Bacteria may develop/reside at this connection resulting in local inflammatory responses (Abrahamsson et al., 1998, Passos et al., 2013). So-called tissue level implants where the mucosal passage constitutes of a collar in continuation of the endosse- 
ous part of the implant does not show this phenomenon (Abrahamsson et al., 1998, Abrahamsson et al., 2002). Following the surgery when installing the implants, remodeling of the alveolar bone occur in the range of approximately $2 \mathrm{~mm}$ during the first year (Cochran et al., 2009). The amount of remodelling may vary and more bone loss has been reported at bone level implants with an external connection, compared to bone level implants with an internal connection, and in bone level implants with an internal connection compared with tissue-level implants (Laurell and Lundgren, 2011).

\section{Microbiological aspects}

The microbiota around dental implants with healthy soft tissue conditions are dominated by gram-positive facultative cocci and rods with gram-negative anaerobic rods present in small numbers (Mombelli et al., 1988, Mombelli and Decaillet, 2011). Thirty minutes after the installation of an implant there is a biofilm in place on the titanium surface (Fürst et al., 2007). Although the surface topography differs between machined and rough titanium surfaces the initial bacterial colonisation is similar (de Melo et al., 2016, Ferreira Ribeiro et al., 2016). Some studies comparing microbiological samples from healthy sites to samples from sites diagnosed with peri-implant mucositis and/or peri-implantitis did not find any significant differences in the microbiota (Renvert et al., 2007, Charalampakis et al., 2012). However, in a later study comparing the microbiome in 47 healthy and 166 peri-implantitis sites using the DNA-DNA checkerboard analysis with a panel of 73 species, a cluster of bacteria including Tanerella forsythia and Staphylococcus aureus was reported to be associated with periimplantitis (Persson and Renvert, 2014). Furthermore, using 16S pyrosequencing to analyse subgingival and submucosal samples from healthy and peri-implantitis sites it was reported that the subgingival microbiome is more complex and differs significantly from the submucosal microbiome at implants both in health and disease (Kumar et al., 2012). 


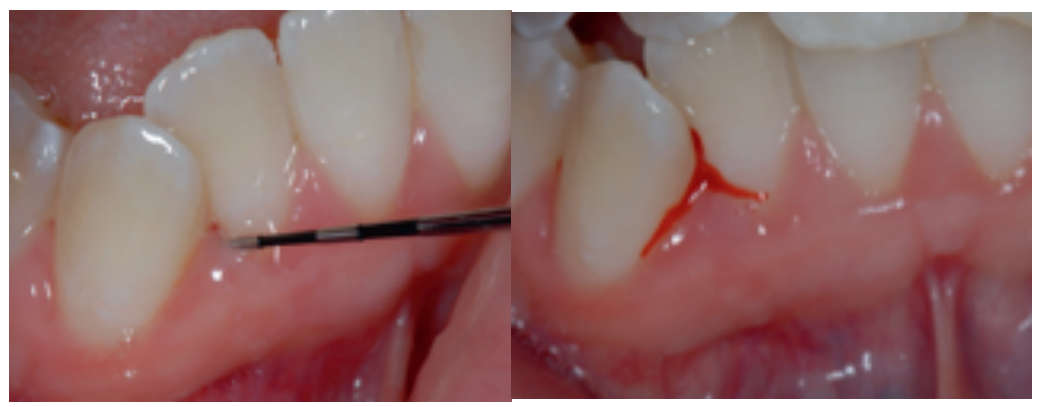

Figure 3. Inflamed gingiva (gingivitis) positive for bleeding on probing, BOP.

\section{Gingivitis}

In 1965 Löe et al. performed an experiment that has become known as "experimental gingivitis in man" (Figure 3). The authors demonstrated that if bacteria in the oral cavity were allowed to form along the gingiva for three weeks, gingivitis occurred and when oral hygiene was reinstituted the inflammation disappeared (Loe et al., 1965). Later studies have demonstrated that the severity and the time-point when the inflammation occurs may vary (Trombelli et al., 2006, Trombelli et al., 2008)

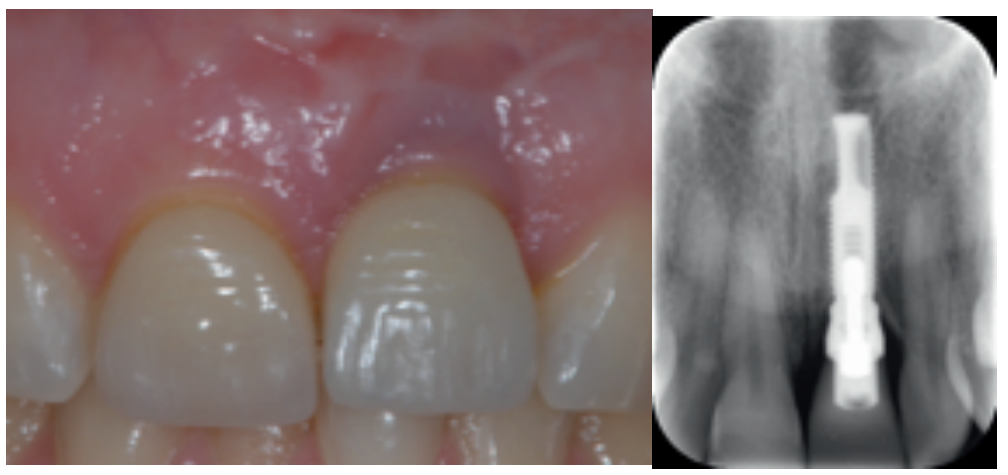

Figure 4. Clinical and radiographic picture of an implant diagnosed with peri-implant mucositis (PiM) 


\section{Peri-implant mucositis}

The reaction to de novo plaque accumulation around implants and teeth is similar and results in an inflammatory reaction (Pontoriero et al., 1994, Zitzmann et al., 2001, Salvi et al., 2012). Peri-implant mucositis (PiM) is defined as a reversible inflammatory lesion limited to the surrounding soft tissues of an osseointegrated implant (Zitzmann and Berglundh, 2008, Lang and Berglundh, 2011, Figuero et al., 2014). Clinically peri-implant mucositis is evidenced by bleeding on probing without any bone loss beyond crestal bone level changes resulting from initial bone remodelling (Figure 4).

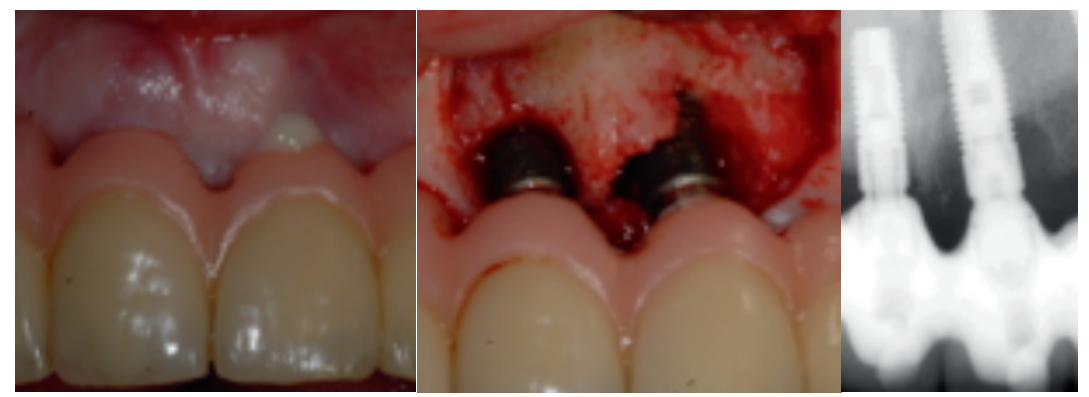

Figure 5. Clinical and radiographic pictures of implants diagnosed with peri-implantitis (PI)

\section{Peri-implantitis}

Peri-implantitis is defined as an inflammatory process around an osseointegrated implant in function, resulting in loss of supporting bone (Lang and Berglundh, 2011). Clinically, peri-implantitis is evidenced by presence of bleeding and/or suppuration on gentle probing and an increased probing depth compared to previous examinations. On radiographs bone loss beyond bone level changes resulting from initial post-installation bone remodeling is present (Figure 5). 


\section{Treatment of gingivitis, peri-implant mucositis and peri-implantitis}

The treatment protocol for gingivitis, peri-implant mucositis and peri-implantitis all includes professional cleaning and training in self-performed dental hygiene procedures. Good daily plaque control is a prerequisite for a successful treatment outcome and participating in a professional maintenance program is beneficial (Pontoriero et al., 1994, Serino and Strom, 2009, Salvi et al., 2012, Costa et al., 2012).

Peri-implant mucositis can convert into peri-implantitis for which there exist no predictable and effective treatment (Jepsen et al., 2015a). Accumulation of plaque on the implant surface is an etiological factor. Self-administered mechanical plaque control is an effective treatment of peri-implant mucositis, professional oral hygiene instructions and debridement improve mucosal health (Jepsen et al., 2015a). Brushing with a dentifrice containing Triclosan during six months reduced the clinical signs of mucositis compared to the use of a regular fluoride dentifrice (Ramberg et al., 2009). Daily use of adjunctive chlorhexidine gel $(0.5 \%)$ for four weeks after mechanical treatment does not enhance the result compared to a placebo gel (Heitz-Mayfield et al., 2011). A recent study, where chlorhexidine gel $(0.2 \%)$ was used while brushing demonstrated a significant reduction of bleeding on probing compared to the use of a placebo gel (Hallstrom et al., 2015a).

Non-surgical treatment of peri-implantitis reduces bleeding on probing and probing pocket depths, but rarely result in control of the disease (Schwarz et al., 2015b). Adjunctive therapies such as the use of an Er: YAG laser, chlorhexidine chip, local antibiotics, glycerine powder air polishing, antimicrobial photodynamic treatment further improved the results of non-surgical therapy alone (Schwarz et al., 2015b).

As non-surgical therapy of peri-implantitis may not result in complete disease resolution, different surgical approaches have been suggested (Schou et al., 2004, Renvert et al., 2008, Renvert et al., 2009, Persson et al., 2010, Figuero et al., 2014). Treatment includes removal of the biofilm and creation of anatomical and prosthetic conditions that makes it possible to maintain oral health. 
The surgical procedure may include bone resection, pocket reduction and/or augmentation of bony defects to accomplish this. To clean the surface, mechanical debridement combined with different chemical procedures has been tested (Carcuac et al., 2015, Carral et al., 2016, Hentenaar et al., 2017). At present no chemical treatment have demonstrated superiority (Claffey et al., 2008). Modifying a rough implant surface using burs and polishing devices (implantoplasty) may improve the treatment result (Romeo et al., 2005, Schwarz et al., 2013).

In connection to surgical therapy of peri-implantitis systemic antibiotics are often prescribed post-operatively although the evidence base is limited (Behneke et al., 2000, Leonhardt et al., 2003, Romeo et al., 2005, Roos-Jansaker et al., 2007, Roccuzzo et al., 2011, Roos-Jansaker et al., 2011, Serino and Turri, 2011, Aghazadeh et al., 2012, Heitz-Mayfield et al., 2012, Roos-Jansaker et al., 2014).

\section{Probiotics}

Probiotics (Greek: for life). At the beginning of the nineteenth century Elie Metchnikoff stated that "lactic bacilli are good for health", and Henri Tessier, a paediatrician, claimed that Bifidobacterium could restore the balance in the gut microbiota after diarrhoea (Metchnikoff, 1907, Teughels et al., 2008). Parker in 1974 introduced the term probiotics, which means "for life"(Parker, 1974). Up until the past three decades treatment using live bacteria were sparsely used and reported treatment results were mostly of an anecdotal character. During the 1980s, the interest increased and in a review 1989 Roy Fuller claimed that a normal balanced gut flora protects against diseases and if disturbed it can be restored using probiotics (Fuller, 1989). During the last twenty-five years, the use of probiotics has become a commercial success and attracted increasing interest from researchers in different fields of medicine.

The Joint FAO/WHO Expert Consultation 2001 defined probiotics as 'Live microorganisms which when administered in adequate amounts confer a health benefit on the host' (WHO). Under normal conditions, probiotics do not permanently colonise the host 
and hence have to be supplied daily (Sinkiewicz et al., 2010). Lactobacillus and Bifidobacterium are lactic acid bacteria and commonly used as probiotics (Teughels et al., 2008). Probiotics can confer health by $a$ ) providing nutrients and co-factors $b$ ) compete with pathogens $c$ ) interact with virulence factors of pathogens and d) stimulate the immune response of the host (Yanine et al., 2013). Probiotics have mainly been used and suggested for treatment of different gut problems. However, during the last decade, the suggested treatment panorama has extended to involve both caries and periodontitis. Probiotics may cause interference with the growth of periodontal pathogens (Saier and Mansour, 2005, Stamatova and Meurman, 2009, Mayanagi et al., 2009). Also, the replacement of pathogens with beneficial bacteria may prevent colonisation by periodontal pathogens (Marcotte et al., 2006).

In-vitro studies have demonstrated that probiotics can inhibit or hamper growth of pathogens associated with periodontal disease (Teughels et al., 2011). Probiotic supplements have in some studies reported improved gingival and periodontal conditions and also altered inflammatory markers in gingival crevicular fluid (Krasse et al., 2006, Shimauchi et al., 2008, Staab et al., 2009, Twetman et al., 2009, Iwamoto et al., 2010, Vivekananda et al., 2010, MartinCabezas et al., 2016). In a randomised clinical cross-over study Flichy-Fernandez et al. demonstrated positive treatment effects of probiotics on peri-implant mucositis (Flichy-Fernandez et al., 2015). Commercially, probiotic bacteria are available in different products e.g. tablets, lozenges, chewing gums and in milk.

\section{Antibiotics}

Antibiotics (Greek: opposing life), kill or slow down the growth of bacteria. Bacteria organised in the submucosal biofilm have a higher tolerance towards antibiotics than bacteria in a planktonic phase (Larsen, 2002, Oettinger-Barak et al., 2013). Systemically administered tetracycline and azithromycin reach higher concentration in GCF and gingival connective tissue than in serum (Lavda et al., 2004, Lai et al., 2011, Raghunatha and George, 2013). Locally delivered antiseptics are at risk of being flushed away due to the flow of peri-implant sulcular fluid. Different slow release local antibiot- 
ics have been developed to have a long-term effect in the treatment of peri-implant diseases (Mombelli et al., 2001, Renvert et al., 2006, Bassetti et al., 2014). There is a lack of scientific evidence whether the additive use of systemic antimicrobials should be recommended as an adjunct to surgical treatment of peri-implantitis and hence there is a need of randomised controlled trials (Sanz and Chapple, 2012). At present only one RCT has evaluated the use of systemic antibiotics in conjunction with surgical treatment of periimplantitis (Carcuac et al., 2016). The additive use of systemic antibiotics did not improve the treatment result following surgical intervention at implants with a non-modified surface whereas an additive effect was reported at implants with a modified surface (Carcuac et al., 2016).

\section{Rationale for the studies}

As peri-implant mucositis is a common condition and may proceed to peri-implantitis, there is a need to evaluate methods to prevent and treat the condition (Ericsson et al., 1992, Derks and Tomasi, 2015, Jepsen et al., 2015a). Mechanical debridement and full mouth disinfection can result in clinical improvement evidenced by reduced pockets, decreased bleeding on probing and reduction of the microbiota over three months (Maximo et al., 2009, ThoneMuhling et al., 2010). Following non-surgical mechanical debridement with or without the addition of a chlorhexidine gel $(0.5 \%)$ complete resolution of BOP at three months was achieved in $38 \%$ of the treated implants (Heitz-Mayfield et al., 2011). Accordingly, there is a need to evaluate other treatment modalities to improve these results. One option could be to use either antibiotics or probiotics in treatment of peri-implant mucositis. Due to the global problem of an increasing number of bacteria resistant to antibiotics, partially caused by the frequent use/misuse of antibiotics, there is a need to clarify whether antibiotics have any place in the treatment of peri-implant mucositis and peri-implantitis (Laxminarayan et al., 2013).

To reduce the use of antibiotics an effective alternative to antibiotics is important. Probiotics have been demonstrated to have beneficial effect, alone or in combination with scaling in the treatment 
of gingivitis and periodontitis (Krasse et al., 2006, Vivekananda et al., 2010, Maekawa and Hajishengallis, 2014). Hence, probiotics might be a candidate to prevent and treat peri-implant mucositis, therebye decreasing the incidence of peri-implantitis. 


\section{AIMS AND HYPOTHESIS}

The objectives of the series of studies presented below were to evaluate the adjunctive effect of antibiotics in the treatment of periimplant mucositis and peri-implantitis and to evaluate the impact of probiotics in preventing and treating peri-implant mucositis.

\section{Study I}

Effect of probiotic lozenges on inflammatory reactions and oral biofilm during experimental gingivitis - a crossover study

Aim: to evaluate whether daily oral administration of probiotic bacteria improves clinical parameters of gingivitis by influencing the composition of the supragingival plaque, clinical parameters and levels of inflammatory mediators in an experimental gingivitis model.

We tested the null hypothesis of no differences in the microbiological profile of supragingival samples or the concentrations of selected cytokines/chemokines in gingival crevicular fluid between the test and the placebo group.

\section{Study II}

Probiotic supplements and debridement of peri-implant mucositis a randomised clinical trial

Aim: to evaluate the effect of probiotic bacteria, applied as topical oil in the gingival sulcus and lozenges for three months, on clinical variables adjacent to implants with a clinical diagnosis of periimplant mucositis. Secondary end-points were effects on inflamma- 
tory mediators in gingival crevicular fluid and composition of the subgingival microbiota.

We tested the null hypothesis of no differences in clinical parameters, microbiota or crevicular fluid between implants treated with probiotics supplemented with lozenges and oil or placebo as an additive to mechanical treatment?

\section{Study III}

Systemic antibiotics and debridement of peri-implant mucositis a randomised clinical trial

Aim: to study the clinical and microbiological results during six months after generalised treatment with azithromycin prescribed during four days as an adjunct to mechanical therapy at implants with a clinical diagnosis of peri-implant mucositis.

We tested the null hypothesis of no differences in clinical and microbiological outcomes over six months between treatment with non-surgical debridement alone, or in combination with systemic administration of azithromycin for four days.

\section{Study IV}

Open flap debridement of peri-implantitis with or without adjunctive systemic antibiotics - a randomised clinical trial

Aim: to evaluate the clinical and microbiological efficacy over 12 months following open flap debridement of implants with the diagnosis of peri-implantitis with or without systemic azithromycin.

We tested the null hypothesis of no differences in clinical and microbiological outcome over 12 months between peri-implant surgery with or without systemic azithromycin during five days after the intervention. 


\section{MATERIAL AND METHODS}

\section{Subjects}

The Regional Ethics Committee at Lund, Sweden approved the four studies. The studies were performed at The Maxillofacial Unit, Halland Hospital, Halmstad between 2008 and 2013. The 18 participants in study I were recruited among staff members at the Maxillofacial Unit at the Halland Hospital, Halmstad, Sweden. Study individuals in studies II-IV (49, 48 and 39 respectively) were recruited among patients referred to the clinic for the treatment of PiM (study II and III), and for the treatment of Pi (study IV).

\section{Case definitions}

Individuals recruited to Study I presented with healthy gingiva adjacent to teeth included in the study. Healthy conditions were defined as no pockets $>3 \mathrm{~mm}$, no BOP, and no bone loss as documented on bite-wing radiographs. The participants were shown pictures of different types of probiotic products and were instructed to abstain from using such products during the study. Before initiation of the study, the participants documented their food intakes during a week in an attempt to control if they used any probiotics. Before study start, the participants had their teeth professionally polished Monday through Friday for two weeks to obtain healthy gingival conditions. Eighteen females participated in this cross-over study.

In studies II and III, peri-implant mucositis was defined by the presence of probing pocket depths $\geq 4 \mathrm{~mm}$, bleeding and/or pus on probing using a force of $0.2 \mathrm{~N}$, but with $<2 \mathrm{~mm}$ of bone loss as as- 
sessed from freshly taken intra-oral dental radiographs in comparison to bone level on radiographs obtained at delivery of the prosthetic reconstruction.

In study IV, peri-implantitis was defined by the presence of interproximal marginal bone loss of $\geq 2 \mathrm{~mm}$ at screening radiographs compared to inter-proximal bone levels on radiographs obtained one year following implant reconstruction combined with probing pocket depth $\geq 5 \mathrm{~mm}$ and with bleeding and/or suppuration on probing. If radiographs from the time of superstructure placement were not available the presence of a distance between implant platform to bone level $\geq 3 \mathrm{~mm}$ bone loss identified from peri-apical radiographs at one year was used. Only one implant per individual was used for study purposes.

\section{Study design}

Study I, is a prospective randomised double-blinded placebo controlled clinical crossover study. Study II is a two-arm prospective double-blinded placebo-controlled randomised clinical trial. Studies III and IV are two arms prospective operator blinded randomised clinical trials.

\section{Study intervention}

In study I, the individuals refrained from oral hygiene of the test teeth for three weeks. During this period lozenges containing L. reuteri (ATCC55730 and ATCC PTA5289) or placebo were taken twice a day until day 21. After a two-week extended washout period, the placebo and test intervention was exchanged between the groups and a new test period started lasting for 21 days.

In studies II and III (peri-implant mucositis) the participants received an individualised oral hygiene instruction, and the selected implants were mechanically debrided with titanium curettes and polished using rubber cup and polishing paste. In study II the treatment session at base-line was finished with the application of a droplet of oil containing probiotics (test) or placebo (control). Lozenges containing either probiotics or placebo were delivered, and the participants were instructed to use the lozenges twice daily for the coming three months. The active oil and lozenges contained 
two Lactobacillus reuteri strains (DSM 17938 and ATCC PTA 5289) (Prodentis, BioGaia AB, Lund, Sweden). In study III, following the non-surgical treatment, the test group received Zithromax ${ }^{\circledR}$ $250 \mathrm{mg} \mathrm{x} 2$ at the day of intervention, and $250 \mathrm{mg} \mathrm{x} 1$ per day for four additional days. The control group did not receive any placebo.

In study IV a mucoperiosteal flap was raised, granulomatous tissue removed, and the selected study implant was cleaned using sterile curettes and saline-soaked cotton gauze. The flaps were repositioned, and neither pocket reduction, nor bone resection was performed. Postoperatively, the test group received Zithromax ${ }^{\circledR} 250$ $\mathrm{mg} \times 2$ starting on the day of surgery, and $250 \mathrm{mg} \times 1$ per day for four days. The control group did not receive a placebo medication.

\section{Outcome parameters and analyses}

\section{Clinical data}

The intervention was in all four studies evaluated using plaque index (PI), bleeding on probing (BOP) and probing pocket depth (PPD). The change in the supragingival microbiota was analysed in study I, and in study II, III and IV the effect of treatment on the subgingival microbiota were evaluated. In study, I and II effect on the total amount of crevicular fluid and selected cytokines in the crevicular fluid was analysed.

In study I, at baseline (day 0) and at follow-up (day 21) registrations were made of PI, gingival index (GI), and BOP.

In study II and III, the following clinical data were collected at baseline and 4, 12, and 26 weeks: full mouth plaque index, local plaque index (presence of dental plaque along the mucosal margin at included implants), probing pocket depths and bleeding on probing graded as; (1) no bleeding; (2) point of bleeding; (3) line of bleeding; and (4) drop of bleeding at the experimental implants. 
In study IV, PI, BOP and PPD scores were recorded at baseline and after 4 and 12 months. All registrations were performed at four sites of the included implant.

\section{Analyses of microbiological data}

In study I supra-gingival plaque collected with sterilised wooden toothpicks at baseline and at follow-up were analysed with the DNA-DNA checkerboard technique with microbial probes for Porphyromonas gingivalis, Prevotella intermedia, Porphyromonas endodontalis, Tannerella forsythia, Aggregatibacter actinomycetemcomitans, Fusobacterium nucleatum, Treponema denticola, Parvimonas micra, Campylobacter rectus, Streptococcus intermedia, Streptococcus oralis, Streptococcus sanguinis, Streptococcus mutans, Veillonella parvula, Actinomyces naeslundii, Filifactor alocis, Lactobacillus reuteri and Lactobacillus fermentum.

In study II subgingival bacteria were sampled using paper-points inserted to the bottom of the implant pocket at baseline, 1, 2, 4, 12, 26 weeks and analysed for the prevalence of Porphyromonas gingivalis, Prevotella intermedia, Prevotella nigrescens, Tannerella forsythia, Aggregatibacter actinomycetemcomitans, Fusobacterium nucleatum, Treponema denticola, Parvimonas micra, Campylobacter rectus, Porphyromonas endodontalis, Filifactor alocis and Prevotella tannerae utilizing the DNA-DNA checkerboard technique.

In study III subgingival bacteria were sampled at baseline, 1, 2, 4, 12, 26 weeks and in study IV at baseline, 2, 6, 12, 26 and 52 weeks using paper-points inserted to the bottom of the implant pocket and analysed with the DNA-DNA checkerboard technique towards a panel of 73 selected bacterial species.

\section{Analysis of gingival crevicular fluid}

In study I gingival crevicular fluid samples (GCF), were collected at baseline and at follow up and in study II at baseline, 1, 2, 4, 12 and 26 weeks with the aid of two separate periopaper strips inserted into the gingival/mucosal sulci for 20 s, following gentle air dry- 
ing. The fluid volumes were recorded using a Periotron 8000 (ProFlow, Amityville, NY, USA), and expressed in $\mu \mathrm{L}$. In study I, the concentration of IL-1 $\beta$, IL-6, IL-8, IL-10, IL-18, TNF- $\alpha$, and MIP- $1 \mathrm{~b}$ and in study II, the levels of IL-1 $\beta$, IL-1RA, IL-4, IL-6, IL8, IL-17A, CCL5, TNF- $\alpha$ IFN-g and GM- CSF were determined. In both studies, commercial Bio-Plex Cytokine Assay kits (Bio-Rad Laboratories, Hercules, CA) were used according to the manufacturer's instructions for the xMAP technology with multiple beads. The cytokine concentrations were expressed as $\mathrm{pg} / \mathrm{mL}$. 


\section{RESULTS}

\section{Study I}

\section{Clinical data}

All subjects exhibited a local accumulation of supragingival plaque and all but one developed gingivitis at the selected test sites during the intervention periods. No significant differences in PI, GI or BOP were displayed between the probiotic test and placebo groups.

\section{Microbiological findings}

Increasing bacterial counts were identified in supra-gingival plaque samples. S. oralis and A. naeslundii were the most prevalent species at baseline and follow-up. T. forsythia, S. mutans and L. fermentum were infrequently identified in all samples. No significant differences were obtained between the groups concerning the microbial species studied. The counts of F. nucleatum and V. parvula increased significantly in both groups during the development of gingivitis $(\mathrm{p}<0.05)$. The counts of $S$. oralis increased only in the probiotic group. Most subjects harboured $L$. reuteri at baseline in both groups, but neither the number of subjects nor the bacterial counts changed markedly during the intervention for L. reuteri.

\section{Inflammatory mediators in GCF}

The volume of gingival crevicular fluid increased in both groups during the experimental periods but was significant $(\mathrm{p}<0.05)$ only in the placebo group. The mean concentrations of TNF- $\alpha$, IL- 6 and IL-10 were not significantly altered between baseline and follow- 
up, whereas IL-1 $\beta$ and IL-18 significantly $(\mathrm{p}<0.05)$ increased at follow-up both in the test and placebo groups. Conversely, the mean concentrations of the chemokine IL- 8 and MIP- $1 \mathrm{~b}$ were significantly $(\mathrm{p}<0.05)$ lower at follow-up compared to baseline.

\section{Conclusion}

Daily intake of probiotic lozenges did not significantly affect plaque accumulation, the composition of the biofilm or the inflammatory reaction during experimental gingivitis.

\section{Study II}

\section{Clinical data}

A general improvement was identified both in the test and in the placebo group at the follow-ups in comparison with baseline, but no significant differences were displayed between the groups. The change in PPD at deepest site at the implant ranged from 0.7-1.2 $\mathrm{mm}$ in both groups. The PPD at three months was significantly lower compared to baseline $(\mathrm{p}<0.05)$. Similarly, the plaque index and bleeding on probing were reduced, with more than $50 \%$ in both groups. The clinical improvements (BOP and PPD) persisted three months after the intervention was terminated.

\section{Microbiological findings}

The most prevalent bacterial species were F. nucleatum, P. micra, $P$. intermedia and $P$. nigrescens. The same four species also displayed the highest counts. Likewise, F. alocis was often prevalent, but only in low counts. P. gingivalis, A. actinomycetemcomitans and $T$. denticola were sparsely detected in all samples. No significant alterations over time or differences between the groups were recorded.

\section{Inflammatory mediators in GCF}

The concentrations of the selected cytokines and chemokines in gingival crevicular fluid reflected the improved clinical health. The volume of GCF decreased in both groups during the intervention 
and at the follow-up $(\mathrm{p}<0.05)$ compared to baseline. There was a tendency of reduced levels of the pro-inflammatory cytokines during the intervention period in both groups compared with baseline, but there were no statistically significant differences between the groups. After four weeks, the levels of IL-1RA, IL-8, CCL5, TNF- $\alpha$ and GM-CSF were significantly lower than at baseline $(\mathrm{p}<0.05)$.

\section{Conclusion}

Mechanical debridement and oral hygiene reinforcement resulted in clinical improvement of peri-implant mucositis and a reduction in cytokine levels. Probiotic supplements did not provide added benefit to placebo.

\section{Study III}

\section{Clinical data}

Mean PI, BOP and PPD were reduced compared to baseline in both groups at all occasions. There were no statistically significant study group differences at 1 st and 3rd month while at six-month registration significantly lower scores were found for full mouth PI $(\mathrm{p}<0.01)$, mean gingival score $(\%)$ at implants $(\mathrm{p}<0.02)$, and for PPD at worst site of implant $(\mathrm{p}<0.05)$ in the test group.

An intent to treat analysis failed to demonstrate study group differences for any of the clinical parameters at baseline or 3rd month after treatment. At the 1 st month examination gingival scores (\%) at implants was lower in the test group $(\mathrm{p}<0.05)$. At the 6th month significantly lower scores were found in the test group for full mouth plaque scores $(\mathrm{p}<0.01)$, mean gingival score $(\%)$ at implants $(\mathrm{p}<0.01)$, full mouth gingival index $(\mathrm{p}<0.05)$ and for probing pocket depth at worst site of implant $(\mathrm{p}<0.05)$.

\section{Microbiological data}

The Kolmogorov-Smirnov test identified that none of the microbial variables presented with a normal distribution pattern. At baseline, the highest counts as determined by mean and median values were found for the following 15 species in decreasing order: Tan- 
nerella forsythia, Fusobacterium nucleatum spp. naviforme (selected to represent Fusobacterium), Campylobacter showae, Campylobacter rectus, Parvimonas micra, Aggregatibacter actinomycetemcomitans (Y4), Eikenella corrodens, Streptococcus pneumonia, Staphylococcus haemolyticus, Pseudomonas aeruginosa, Prevotella intermedia, Prevotella melaninogenica, Treponema socranskii, Staphylococcus aureus, and Porphyromonas gingivalis.

At all time-points, using either the per-protocol analysis or the intent to treat protocol, statistical analysis failed to demonstrate significant study group differences in bacterial counts for all bacterial species studied. Statistical analysis also was unable to confirm study group differences in the changes of bacterial counts between baseline and the 3rd, and the 6th months respectively. Furthermore, statistical analysis by intent to treat failed to identify withingroup differences comparing baseline data with all other time points $(1,2,4,12$ and 26 weeks). At four weeks after treatment, trends ( $\mathrm{p}<0.05$ ) of lower counts were found for F. nucl spp. naviforme, S. pneumoniae, P. intermedia, T. forsythia, and T. denticola but only at this time point and just for the test group.

\section{Conclusion}

No short-term differences were found between study groups. The present study does not provide evidence for the use of systemic antibiotics in treatment of peri-implant mucositis.

\section{Study IV}

\section{Clinical data}

At baseline, all implants bled on probing. At six-months 7\% in the test group and $6,3 \%$ in the control group demonstrated bleeding on probing. Corresponding figures at 12 months were $13,3 \%$ in the test group and $37,5 \%$ in the control group. Statistical analysis failed to demonstrate differences in bleeding on probing by study group assignment $(\mathrm{p}=0.1)$. 
Results from analysis between study groups by independent $t$-test (equal variances not assumed) of probing depth and radiographic bone levels are reported. Data analyses based on mean probing pocket depth, and radiographic bone level values failed to show group differences at time points assessed. Hence, data analysis was unable to demonstrate study group difference for the primary outcome measure.

\section{Microbiological findings}

At twelve months, 8/31 (25.8\%) individuals presented with no detectable level of nine bacterial species included in the cluster of bacteria explicitly associated with peri-implantitis (Persson and Renvert, 2014). Statistical analysis by Mann Whitney-U tests failed to identify differences between test and control groups for the total bacterial load (sum of DNA of selected bacterial species in the cluster group of bacteria) at all time points ( $\mathrm{p}$-values varying between 0.51 to 1.0 ). When changes in bacterial load over time were compared to the baseline values, data analysis failed to demonstrate group differences in bacterial load. The microbiological analysis by per protocol and intent to treat gave similar results. Trends of decreasing bacterial loads were found between baseline, two and four weeks in both the experimental and the control groups. Such reductions were not retained at later time-points. Based on successful clinical outcome, defined as PPD $\leq 5 \mathrm{~mm}$, no suppuration, no BOP at the implant sites, and bone loss $\leq 0.5 \mathrm{~mm}$ between baseline and year one, no differences in changes of bacterial load were found between successfully and non-successfully treated implants.

\section{Conclusion}

Surgical open flap debridement of peri-implantitis with adjunctive systemic azithromycin did not provide any one-year clinical benefits in comparison to those only receiving open flap debridement. 


\section{DISCUSSION}

The rationale for the studies in this thesis was: (I) the reported high rate of soft-tissue complications around dental implants, (II) recent data suggesting benefits of probiotics in periodontal therapy, and (III) the frequent use of systemic antibiotics when treating periimplant inflammation without clear evidence of treatment efficacy.

Sites having a clinical probing depth $\geq 4 \mathrm{~mm}$ in conjunction with bleeding and/or suppuration on probing using a probing force of $0.2 \mathrm{~N}$, and bone-loss $\leq 2 \mathrm{~mm}$ on present radiographs compared to radiographs taken at the time of prosthetic delivery was diagnosed as peri-implant mucositis (studies II and III). At healthy periodontal sites, using a probing force of $0.2 \mathrm{~N}$ the probe tip reaches the most apical part of the junctional epithelium (Lang et al., 1994). When gingival and peri-implant tissues are inflamed, the probe penetrates deeper than at healthy sites and deeper into peri-implant tissue compared to gingiva (Ericsson and Lindhe, 1993, Lang et al., 1994, Schou et al., 2002). Bleeding on probing (studies II-IV) has been used and recommended as a discriminating factor assessing health and disease at dental implants (Jepsen et al., 2015a). Bleeding can, however, be initiated by the trauma induced by probing of the peri-implant tissues and may not necessarily be associated with disease (Ericsson and Lindhe, 1993). A graded bleeding index may, however, improve the evaluation of BOP values. To assess differences between peri-implant mucositis and peri-implantitis changes in bone levels beyond the initial bone remodelling is considered as a discriminating factor (Lang and Berglundh, 2011). 
In studies II-IV, radiographs were used to study alveolar bone levels at implants to assess the presence and extent of bone loss. Bone-loss beyond the radiological measurement error in combination with inflammation has been proposed to define periimplantitis (Sanz and Chapple, 2012). Radiographs taken at the time of prosthesis delivery should be used as reference for future assessment of implant conditions and confirm a diagnosis of periimplantitis or not (Lindhe et al., 2008). The actual bone loss at dental implants is, however, under-estimated when assessed from peri-apical radiographs (Serino et al., 2017, Christiaens et al., 2018). Newer methods, using three-dimensional (3D) image superimposition, measuring volumetric bone changes around implants has however demonstrated a correlation between direct measures on periapical radiographs and volumetric measurements on Cone Beam Computed Tomography (Villarinho et al., 2018). In the present study, intra-oral conventional long-cone $\mathrm{X}$-rays over time was used to assess bone level changes.

The association between the presence of plaque and the development of peri-implant mucositis has been demonstrated (Lindquist et al., 1988, Ericsson et al., 1992, Pontoriero et al., 1994, Zitzmann et al., 2001, Lang and Berglundh, 2011). An increased amount of plaque has also been reported at sites diagnosed with peri-implant mucositis and peri-implantitis. Since bacterial plaque is an essential factor for the development of peri-implant diseases microbiological analyses were included in the thesis (Studies I-IV). The peri-implant microbiota was assessed before and after study intervention. The supragingival bacterial samples in study I was collected with sterilised wooden sticks. In study II-IV, microbial samples were collected with paper strips. Paper strip harvesting of sub-gingival microorganisms has been shown to give a higher variation and magnitude of microorganisms compared to the use of curettes (Gerber et al., 2006). In all studies, the microbial samples were analysed with the checkerboard DNA-DNA hybridisation technique either at the microbiology laboratory at the University of Gothenburg, Sweden (Study I, and II), or the microbiology laboratory at the University of Bern, Switzerland (Studies III, and IV). Studies have shown that the checkerboard method has a high level 
of agreement with conventional anaerobic and aerobic culture methods (Moncla et al., 1994, Socransky et al., 2004).

In a study testing the reproducibility, the authors concluded that subsequent subgingival samples analysed with checkerboard DNADNA hybridisation displayed an acceptable reproducibility between repeated samples (Hallstrom et al., 2015c). The checkerboard DNA-DNA hybridisation technique allows identification of both dead and alive bacteria whereas culture methods only detect living organisms. Checkerboard analyses only identify the presence of DNA-DNA signals against reference strains whereas culture methods are specific to culturing methods, i.e. growth media. Today there are methods to analyse the biofilm sample on all its nucleic acid sequences and then by comparing the found sequences with e.g. the Human Oral Microbiome Database identify all bacteria in the biofilm, and thereby overcome some of the limitations associated with culturing and checkerboard analyses (Kilian et al., 2016). In addition to the microbiological assays, levels of proinflammatory cytokines in peri-implant crevicular fluid samples were studied using multiplex technology (studies I, and II).

Results from a data analysis showed that levels of proinflammatory cytokines might predict peri-implantitis (Wang et al., 2016a, Wang et al., 2016b), and levels of interleukins Il-1 $\beta$, IL-6, TNF- $\alpha$, have been linked to the clinical response (Ata- Ali et al., 2015). In studies, I, and II the levels of cytokines were used to assess clinical responses to the study interventions.

An experimental gingivitis study was chosen to evaluate the effects of additive probiotics on the development of gingival inflammation. By inviting the clinical staff of the department to participate in this study we tried to minimise the impact of lousy compliance, and using a custom-made splint also lowered the risk for accidental brushing. Tissue reaction to plaque accumulation is reported to be different between individuals (Trombelli et al., 2004) and we, therefore, used a crossover study design.

Probiotics have been tested both as primary and secondary prevention for oral diseases.

In Study I, no significant differences in PI, GI or BOP were found between the two tested modalities. The volume of gingival crevicu- 
lar fluid increased in both test and control groups, but only statistically significant in the placebo group. The concentration of TNF- $\alpha$ and IL-1 $\beta$ also increased with increasing gingival inflammation. These findings are in agreement with another study (Offenbacher et al., 2010).

In a previous study using chewing gums containing two strains of Lactobacillus reuteri: ATCC 55730 and ATCC PTA 5289, a significant reduction of TNF- $\alpha$ and IL-8 levels $(\mathrm{p}<0.05)$ were reported in adults with moderate gingivitis (Twetman et al., 2009). Such effects could not be identified in the experimentally induced gingivitis study (Study I). It is possible that the use of chewing gums is more efficient than the distribution of probiotic microorganisms via lozenges. It is also possible that differences in the strains used in the two products could affect the results. In Study, I, DSM 17938 and ATCC PTA 5289 strains were used whereas in the study by Twetman et al. (2009) different lactobacilli (strains ATCC 55730 and ATCC PTA 5289) were used. Furthermore, the studies on the effects of probiotics to control inflammation in established gingivitis lesions may be entirely different from the effects of an experimental gingivitis model that resembles the development of an acute inflammatory process.

Several studies have been performed aiming at reducing and changing the biofilm on the implant surface preventing the reestablishment of a pathologic biofilm (Salvi et al., 2012, Pontoriero et al., 1994, Zitzmann et al., 2001, Schwarz et al., 2015a). Nonsurgical debridement and oral hygiene instructions result in reduced bleeding on probing even if it does not entirely resolve the inflammation (Heitz-Mayfield et al., 2012, Maximo et al., 2009, Thone-Muhling et al., 2010) which was confirmed in this thesis (Studies II, and III). Non-surgical debridement alone is considered as the golden standard of initial therapy to which any additive interventions or home care anti-infective substances should be evaluated. Among tested additives to non-surgical therapy are minocycline microspheres, chlorhexidine (rinsing or gel), tetracycline fibres, air polishing with glycine powder (Figuero et al., 2014). None of these additive treatment modalities has demonstrated statistical- 
ly significant advantages compared to standard of care (Schwarz et al., 2015a). One study using tooth brushing with a chlorhexidine gel reported a substantial reduction of BOP while another similar study did not (Heitz-Mayfield et al., 2011, Hallstrom et al., 2015a). Data also suggest that a dentifrice containing triclosan can reduce the extent of bleeding on probing compared to using a sodium fluoride dentifrice (Ramberg et al., 2009).

There are some studies on probiotics in the treatment of gingivitis and periodontitis demonstrating significant reductions in clinical inflammatory parameters (Krasse et al., 2006, Vivekananda et al., 2010). An effect on the subgingival microbiota without any significant impact on the inflammatory response has been reported (Iniesta et al., 2012, Montero et al., 2017). As of March 2018, a search on PubMed on "peri-implant mucositis and probiotics" yielded five studies (Flichy-Fernandez et al., 2015, Hallstrom et al., 2015b, Mongardini et al., 2017, Tada et al., 2017, Galofre et al., 2018). The results are difficult to compare since the design, inclusion and diagnostic criteria and parameters used for evaluation differ. In Hallstrom et al. (2015) study II all subjects received subgingival mechanical debridement with titanium curettes, OHI and were polished. In the studies by Flichy-Fernandez et al., (2015) and Galofre et al. (2018) only supragingival debridement were performed. In the study by Tada et al. (2017) supragingival debridement was combined with the use Azithromax ${ }^{\circledR}$ and in the study by Mongardini et al. (2017) supragingival debridement was supplemented with photodynamic biolight (Table 1). Subgingival debridement and $\mathrm{OHI}$ reduces $\mathrm{BOP}$ in PiM cases but does not lead to complete resolution of inflammation (Heitz-Mayfield et al., 2011). Studies on experimentally induced PiM have shown that reinstituted oral hygiene result in resolution of inflammation (Pontoriero et al., 1994, Salvi et al., 2012). 
Table 1. Treatment outcome measured as bleeding index and group differences. "Yes" means a significant reduction in bleeding index or difference between test and control $(\mathrm{p}<0.05)$.

\begin{tabular}{|l|l|l|l|l|l|}
\hline $\begin{array}{l}\text { Author, year } \\
\text { Treatment at baseline }\end{array}$ & Diagnosis & Index & $\begin{array}{l}\text { Probiotics } \\
\text { reduction }\end{array}$ & $\begin{array}{l}\text { Placebo } \\
\text { reduction }\end{array}$ & $\begin{array}{l}\text { Group } \\
\text { difference }\end{array}$ \\
\hline $\begin{array}{l}\text { (Galofre et al., 2018) } \\
\text { Supra gingival prophylaxis }\end{array}$ & PiM & BOP & Yes & No & Yes \\
\hline $\begin{array}{l}\text { (Tada et al., 2017) } \\
\text { OHI, supra gingival scaling, } \\
\text { Azithromax }\end{array}$ & Pi (mild) & mBI & No & No & Yes \\
\hline $\begin{array}{l}\text { (Mongardini et al., 2017) } \\
\text { OHI, plaque removal } \\
\text { photodynamic therapy }\end{array}$ & PiM & BOP & Yes & Yes & No \\
\hline $\begin{array}{l}\text { (Hallstrom et al., 2015b) } \\
\text { OHI, mechanical debridement }\end{array}$ & PiM & BOP & Yes & Yes & No \\
\hline $\begin{array}{l}\text { (Flichy-Fernandez et al., 2015) } \\
\text { Supra gingival prophylaxis }\end{array}$ & PiM & mGI & No & No & No \\
\hline
\end{tabular}

In study II, the results failed to identify differences between active and placebo groups regarding the microbiota and clinical outcome measures. However placebo should not be confused with no treatment as there is solid evidence that placebo can have an effect even on physiological data as well as the fact that just participating in a study can alter disease parameters. It has been demonstrated that the additive of a tasty non-effective placebo to an immunosuppressing medication can "teach" individuals to suppress the immune response and later exposition to the placebo alone will lower the immune response measured as T-cell activity (Owens et al., 1997, Feil et al., 2002, Albring et al., 2014).

Systemic administration of Azithromycin ${ }^{\circledR}$ (Sandoz AS, Copenhagen, Denmark) has proven useful in the treatment of adult periodontitis (Smith et al., 2002, Mascarenhas et al., 2005, Haas et al., 2008, Yashima et al., 2009). At the time of initiation of Study III, no data were available on the additive effects of Azithromycin ${ }^{\circledR}$ in the treatment of peri-implant mucositis. Therefore, the impact on 
the management of peri-implant mucositis using adjunct Azithromycin ${ }^{\circledR}$ was studied. At three months, a trend towards lower bacterial counts was found in the test group. At six months, however, there was no difference between study groups. A general trend of increasing microbiological numbers was, however, identified over time following an initial reduction shortly after antibiotic intake. Similar results have been determined elsewhere in the treatment of periodontitis (Yashima et al., 2009). At six months, the test group demonstrated more significant reduction of bleeding on probing and probing pocket depth compared to the control group. This difference between groups, observed at six months, was not found earlier in the study and could be explained by the superior plaque control in the test group rather than the effect of antibiotic treatment six months before registration. Thus, the adjunct therapy with systemic antibiotics in the management of peri-implant mucositis considering the overall risks for development of antibiotic resistance is not warranted.

There is a correlation between clinical signs of bleeding on probing and the histological level of mucositis and therefore BOP is considered a key parameter to distinguish between health and disease at implants (Lang et al., 1994, Lang and Berglundh, 2011, Tonetti et al., 2015). Hence, reporting and evaluating the treatment results from peri-implant mucositis studies, bleeding on probing is often used as the primary outcome parameter. BOP is often reported as the proportion of bleeding sites at baseline and follow ups. The four study groups in study II and III demonstrated, measured on implant level $100 \%$ BOP at BL and reduction to $80-90 \%$ at 26 weeks and at surface level $80 \%$ BOP at BL and reduction to 30 $45 \%$ at 26 weeks. If a point of bleeding is interpreted as disease $80-90 \%$ of the implants would be classified as diseased compared to $30-45 \%$ of the surfaces. (Figure 6 and 7). The dichotomous character of BOP registrations shows the extension of inflammation but says nothing about the severity. By grading the bleeding $0=$ none, 1 =point, $2=$ line and $3=$ drop, (Mombelli et al., 1987). Information about the severity is added to the status (Figure 8). 


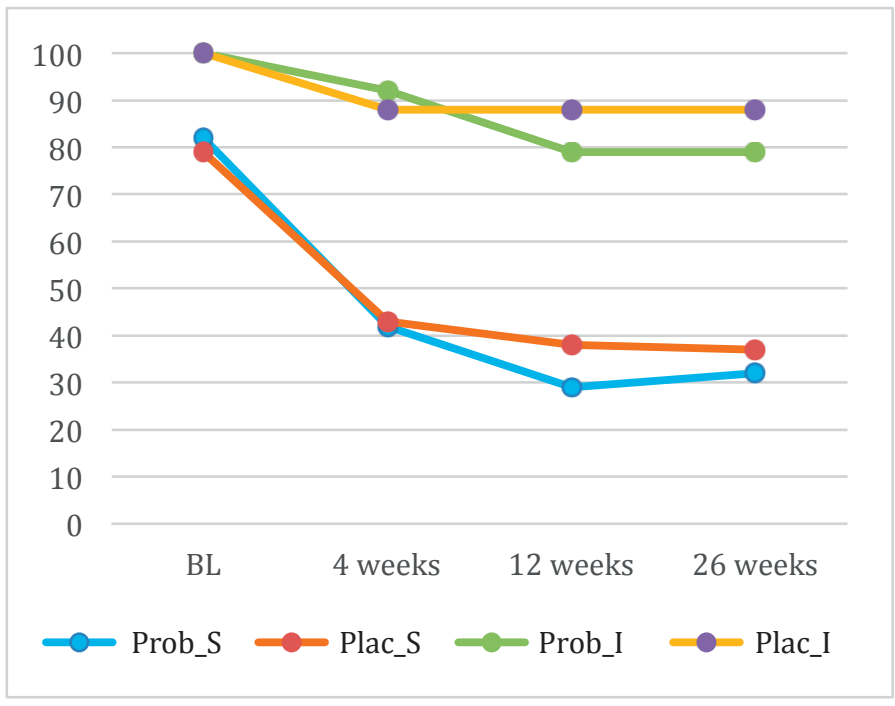

Figure 6. BOP expressed as proportion (\%) of surfaces (S) and of implants (I) at BL and follow ups 4, 12 and 26 weeks. (Prob=probiotics; Plac=placebo)

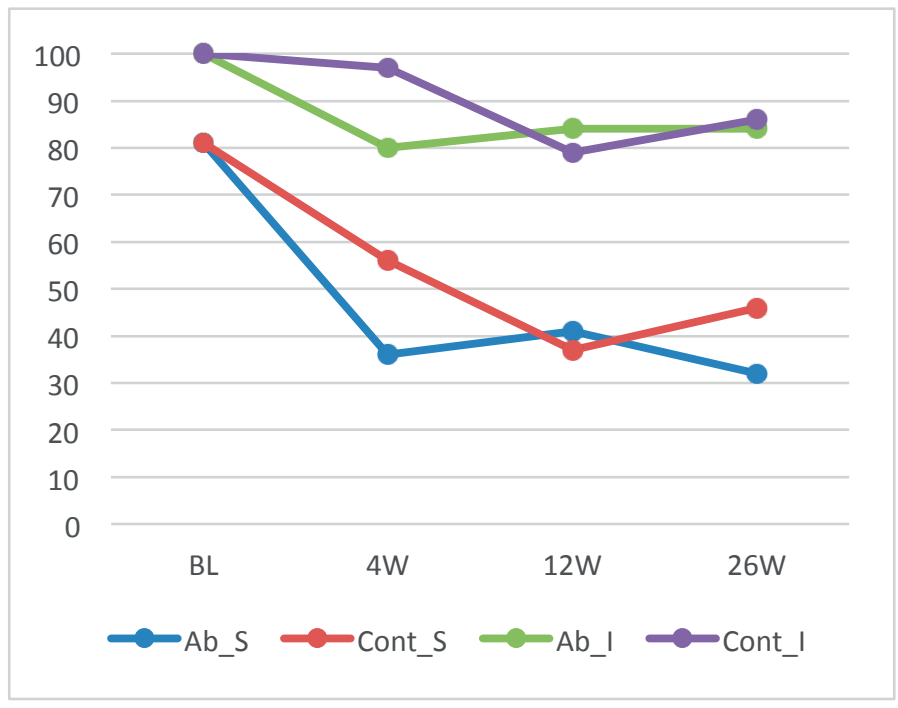

Figure 7. BOP expressed as proportion (\%) of surfaces (S) and of implants (I) at BL and follow ups 4, 12 and 26 weeks. (Ab=antibiotics; Cont $=$ control) 


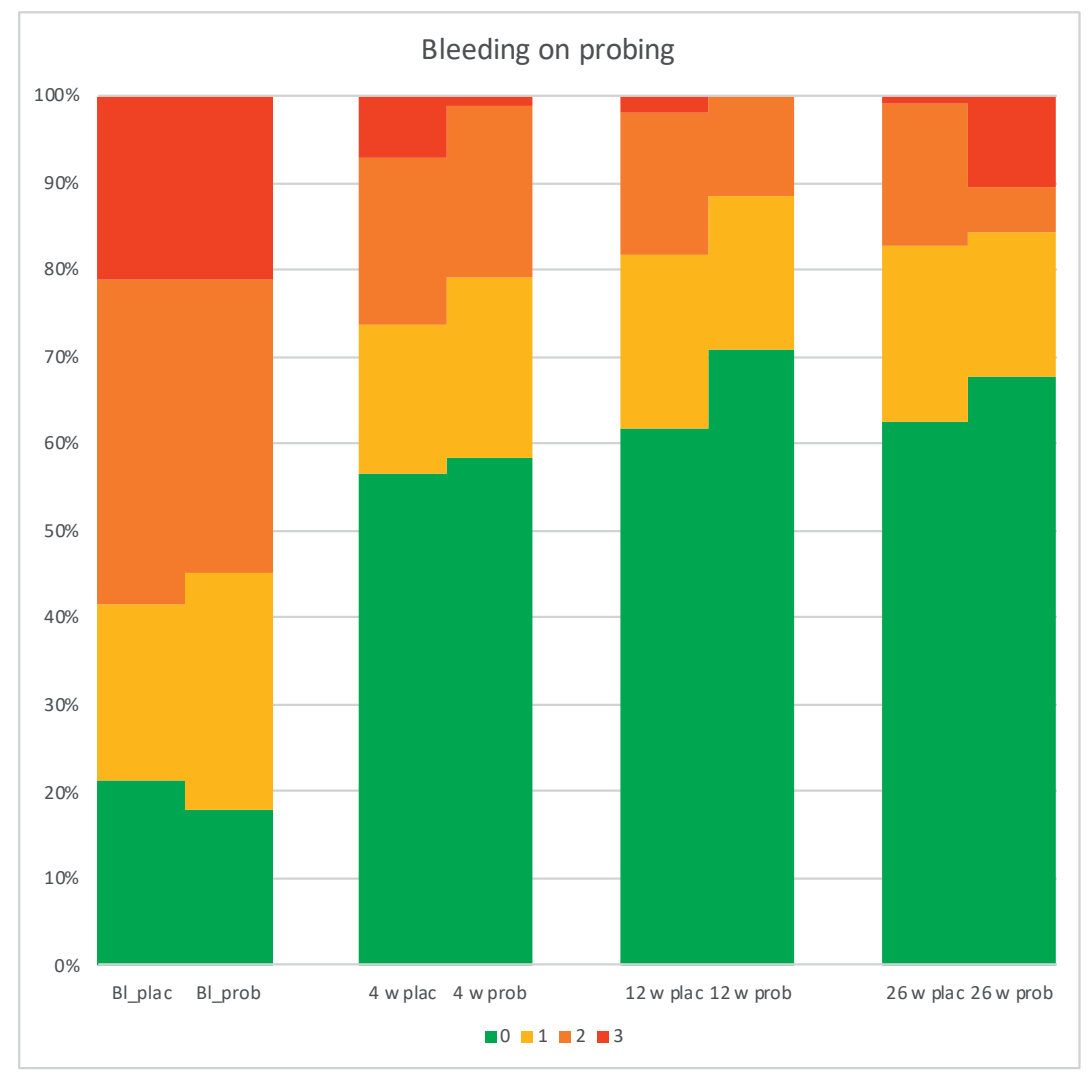

Figure 8. Bleeding on probing (\%) at BL, 4, 12 and 26 weeks. (0) no bleeding, (1) point of bleeding, (2) line of bleeding and (3) drop of bleeding. Plac=placebo, prob=probiotic. 
The optimal goal of the treatment of peri-implantitis would be to change the biofilm at implants to what might be associated with healthy conditions, reinstituting clinical health, and allow regeneration of lost bone adjacent to the implant. A more realistic goal may be to resolve the inflammation preventing the progression of the disease (Lindhe et al., 2008, Heitz-Mayfield et al., 2012). Available data suggest that non-surgical treatment of peri-implantitis has a low efficacy and that surgical treatment is considered the method of choice (Persson et al., 2010, Persson et al., 2011, Roos-Jansaker et al., 2015).

Surgical treatment of peri-implantitis usually includes open-flap debridement and decontamination of the implant surface (Sanz and Chapple, 2012). Systemic administration of antibiotics is commonly used in combination with surgical treatment of peri-implantitis (Graziani et al., 2012, Renvert et al., 2012). Approximately 70\% of American periodontists have reported that they used systemic antibiotics in some cases when treating peri-implant mucositis, and in about $90 \%$ in the treatment of peri-implantitis (Papathanasiou et al., 2016). Recently it was, however, demonstrated that additive systemic antibiotics might only improve treatment results when performing peri-implantitis surgery on implants with a modified surface while there was no such beneficial effect at "non-modified surface implants" (Carcuac et al., 2016).

Reductions in bacterial loads at three and six months after surgery were obtained in both test and control groups. At twelve months, however, increasing bacterial counts were identified in both study groups. Thus, the data determined that the antibiotic prescription accordingly failed to prevent recolonization following therapy suggesting that the administration of adjunctive antibiotics provides no added values compared to surgical intervention alone. The fact that bacterial colonisation after intervention occurred are consistent with six month data reported in a previous study (Renvert et al., 2016). The clinical results of surgical intervention at peri-implantitis sites as reported in study IV are consistent with data reported in recent reviews (Renvert and Polyzois, 2015, Ramanauskaite et al., 2016). 


\section{CONCLUSIONS}

Daily intake of probiotics does not affect supragingival plaque accumulation compared to placebo administration during the development of experimental gingivitis

Probiotic supplements do not add benefits to placebo regarding the impact on the subgingival microflora, on pro-inflammatory cytokines or oral clinical parameters during the development of experimental gingivitis

Adjunctive systemic administration of azithromycin to non-surgical debridement and oral hygiene instructions in the treatment of periimplant mucositis does not provide additional clinical benefits when compared to routine non-surgical debridement without the use of systemic antibiotics

Systemic intake of azithromycin as adjunct to surgical open flap debridement in the treatment of peri-implantitis does not provide additional clinical benefits at twelve months when compared to routine surgical debridement without the use of systemic antibiotics 


\section{FUTURE RESEARCH}

There is an urgent need for additional clinical studies on the prevention and treatment of peri-implant inflammations. Currently, few randomised clinical trials exist. Additionally, it is important to further elucidate risk indicators for peri-implant infections. This should be done in order to allow clinicians to minimise the risk of future peri-implant diseases by proper patient selection, choice of implants, surgical method and in the design of the prosthetic reconstruction. There is a further need to explore the possibilities of developing the prosthesis and other hardware products in a way that they may delay or even prevent the development of periimplant diseases, e.g. the development of antibacterial properties on dental implant surfaces.

Even if the addition of probiotics did not result in a beneficial treatment effect in our studies, the additive use of probiotics in the treatment of infections is a promising field of research were others have shown interesting results. There are other ways of administering probiotics and also other bacterial strains that could be used than the ones used in this thesis. 


\section{CLINICAL RECOMMENDATIONS}

As peri-implant mucositis is common and precedes the development of peri-implantitis future treatment strategies and research should be oriented towards prevention and treatment of periimplant-mucositis.

For clinicians, it is therefore important to;

- Design the prosthetic construction so that it facilitates a good plaque control

- Involve implant patients in a structured maintenance program

- Register bleeding on probing and pocket depth at least once yearly

- Perform non-surgical therapy at sites demonstrating bleeding on gentle probing

- Reinforce patients' oral hygiene procedures 


\section{POPULÄRVETENSKAPLIG SAMMANFATTNING}

Ett ökande antal individer har artificiella tänder som är förankrade till implantat i käkarna. Den moderna tandimplantatsbehandlingen är en svensk upptäckt som blev tillgänglig för patienter under 1970-talet. Detta tillsammans med det faktum att behandlingen ingår i det allmänfinansierade tandvårdsstödet har inneburit att det $\mathrm{i}$ Sverige är vanligt med implantat och att många patienter har haft sina implantat under lång tid.

Långtidsresultaten för implantatbehandling är goda och många har haft sina konstruktioner i tiotals år. Men som med all behandling förekommer det komplikationer. Dels tekniska komplikationer, vanligtvis frakturer eller lossade skruvar i tandersättningsdelen, men också frakturer av implantaten som är förankrade i käken och bär dessa konstruktioner. Biologiska komplikationer förekommer framförallt i två former, peri-implantär mukosit och peri-implantit. Peri-implantär mukosit är en inflammation i slemhinnan runt ett implantat. I en del fall utvecklas denna inflammation till periimplantit som innebär att inflammationen också involverar och bryter ner käkbenet vilket på sikt kan leda till att implantatet lossnar. Förekomsten av biologiska komplikationer ökar desto längre implantaten varit i funktion och beroende på detta, samt hur man väljer att definiera peri-implantär mukosit och peri-implantit så är den rapporterade förekomsten $19-65 \%$ respektive $1-47 \%$.

Behandlingen av inflammationer kring implantat består framförallt av att tandvårdspersonal ger hygieninstruktioner till patienten samt avlägsnar bakterier och tandsten på implantaten. I de fall där 
käkbenet blivit involverat så krävs ofta dessutom kirurgi. Inte sällan kompletteras behandlingen med antibiotika. Oavsett behandlingsform så uppnås sällan fullständig utläkning och trots att antibiotika ofta används är det inte belagt huruvida detta förbättrar behandlingsresultatet. Utvecklingen av bakterier som är resistenta mot antibiotika är ett stort och globalt problem. Frekvent användande av antibiotika är en faktor som ökar resistensutvecklingen i samhället och därför ska antibiotika användas endast när det erfordras och är effektivt. Probiotika är levande bakterier som, givit i adekvat dos, har en positiv inverkan på den behandlade individen, det vill säga en hämmande eller läkande effekt på inflammationer kring implantat.

Målet med denna avhandling är att klargöra huruvida systemiskt administrerad antibiotika förbättrar behandlingsresultatet vid behandling av peri-implantär mukosit och peri-implantit och om probiotika kan förebygga uppkomsten av inflammationer kring implantat eller förbättra behandlingsresultatet.

Avhandlingen består av fyra studier som på patient undersökt,

- om sugtabletter med probiotika kan hindra eller mildra uppkomsten av inflammation i tandköttet när man avstår från att borsta tänderna

- om sugtabletter med probiotika förbättrar resultatet vid behandling av peri-implantär mukosit

- om antibiotika givet i tablettform förbättrar resultatet vid behandling av peri-implantär mukosit

- om antibiotika givet i tablettform förbättrar resultatet vid kirurgisk behandling av peri-implantit

Avhandlingsarbetena visar,

- att dagligt intag av sugtabletter med probiotika inte hämmar eller förhindrar uppkomsten av inflammation i tandköttet när man avstår från att borsta tänderna

- att dagligt intag av sugtabletter med probiotika som tillägg till munhygien instruktion och mekanisk rengöring av implantat vid peri-implantär mukosit inte förbättrar behandlingsresultatet 
- att tabletter med azitromycin som tillägg till hygieninstruktion och mekanisk rengöring av implantat vid peri-implantär mukosit inte förbättrar behandlingsresultatet

- att tabletter med azitromycin som tillägg till hygieninstruktion och operation med mekanisk rengöring av implantat vid periimplantit inte förbättrar behandlingsresultatet

- att hygieninstruktion och mekanisk rengöring vid periimplantär mukosit leder till minskad inflammationsgrad

- att hygieninstruktion och operation med mekanisk rengöring vid peri-implantit leder till minskade fickdjup och viss återväxt av käkben 


\section{ACKNOWLEDGEMENTS}

I would like to express my gratitude to all the people who made this thesis possible.

Among these people a special mention goes to:

Stefan Renvert, for inviting me to the initial studies and later convincing me to become a doctoral student. Your confidence, patience, and support throughout the project have been invaluable.

Svante Twetman, for introducing me to probiotics and for providing unlimited support and inspiring discussions. "If we were having this discussion as academics two hundred years ago we would probably have been speaking French".

Susann Lindgren, for keeping track of everything, all practical patient treatment as well as your support when I have been in doubt.

Rutger Persson, for sharing your expertise in microbiology and statistics and your assistance and dedication to ensuring that our articles were published.

Andreas Stavropoulos, for perceptive, encouraging and robust advice throughout the final stages of my work on this thesis. 
Maria Olofsson, Tulay Yucel-Lindberg, Gunnar Dahlén and Cecilia Widén, for the practical work and analysis performed in the studies.

Sten Isaksson, for giving me the green light and providing the opportunities needed to commence the studies. I am also grateful for your willingness to share your constantly positive attitude in combination with your unwillingness to accept anything to be impossible.

Anders Holmén, for your enthusiastic and competent computer assistance and advice concerning statistical analysis.

Selma Stojisavljevic, for all the help with administrating patients and especially for, with great integrity, keeping the secrets of placebo and active substances blinded to the rest of us involved in the studies.

Cecilia Hallström Parker, for lending your sharp linguistic eye to the thesis and ensuring the language makes sense.

The fantastic staff at Specialisttandvården, Hallands sjukhus, Halmstad for being the most positive group I have worked with you are always ready to help and lend me a share of your respective competences.

Lars-Åke Johansson for the meticulous reading of the thesis as well as professional advice delivered during long and enjoyable discussions about everything and nothing.

Björn Klinge, for being a robust academic navigator throughout this thesis journey.

Eva, Cecilia, Johanna, and Viktor, for constantly cheering me on and for your patience. 


\section{REFERENCES}

ABRAHAMSSON, I., BERGLUNDH, T. \& LINDHE, J. 1998. Soft tissue response to plaque formation at different implant systems. A comparative study in the dog. Clin Oral Implants Res, 9, 73-9.

ABRAHAMSSON, I., BERGLUNDH, T., WENNSTROM, J. \& LINDHE, J. 1996. The peri-implant hard and soft tissues at different implant systems. A comparative study in the dog. Clin Oral Implants Res, 7, 212-9.

ABRAHAMSSON, I., ZITZMANN, N. U., BERGLUNDH, T., LINDER, E., WENNERBERG, A. \& LINDHE, J. 2002. The mucosal attachment to titanium implants with different surface characteristics: an experimental study in dogs. J Clin Periodontol, 29, 448-55.

AGHAZADEH, A., RUTGER PERSSON, G. \& RENVERT, S. 2012. A single-centre randomized controlled clinical trial on the adjunct treatment of intra-bony defects with autogenous bone or a xenograft: results after 12 months. J Clin Periodontol, 39, 666-73.

ALBRING, A., WENDT, L., BENSON, S., NISSEN, S., YAVUZ, Z., ENGLER, H., WITZKE, O. \& SCHEDLOWSKI, M. 2014. Preserving learned immunosuppressive placebo response: perspectives for clinical application. Clin Pharmacol Ther, 96, 247-55.

ANONYMOUS 2013. Peri-implant mucositis and peri-implantitis: a current understanding of their diagnoses and clinical implications. J Periodontol, 84, 436-43.

BASSETTI, M., SCHAR, D., WICKI, B., EICK, S., RAMSEIER, C. A., ARWEILER, N. B., SCULEAN, A. \& SALVI, G. E. 2014. Anti-infective therapy of peri-implantitis with adjunctive local drug delivery or photodynamic therapy: 12-month outcomes 
of a randomized controlled clinical trial. Clin Oral Implants Res, 25, 279-87.

BEHNEKE, A., BEHNEKE, N. \& D'HOEDT, B. 2000. Treatment of peri-implantitis defects with autogenous bone grafts: sixmonth to 3-year results of a prospective study in 17 patients. Int J Oral Maxillofac Implants, 15, 125-38.

BERGLUNDH, T. \& LINDHE, J. 1996. Dimension of the periimplant mucosa. Biological width revisited. J Clin Periodontol, 23, 971-3.

BERGLUNDH, T., LINDHE, J., ERICSSON, I., MARINELLO, C. P., LILJENBERG, B. \& THOMSEN, P. 1991. The soft tissue barrier at implants and teeth. Clin Oral Implants Res, 2, $81-90$.

BUSER, D., WEBER, H. P., DONATH, K., FIORELLINI, J. P., PAQUETTE, D. W. \& WILLIAMS, R. C. 1992. Soft tissue reactions to non-submerged unloaded titanium implants in beagle dogs. J Periodontol, 63, 225-35.

CARCUAC, O., DERKS, J., CHARALAMPAKIS, G., ABRAHAMSSON, I., WENNSTROM, J. \& BERGLUNDH, T. 2015. Adjunctive Systemic and Local Antimicrobial Therapy in the Surgical Treatment of Peri-implantitis: A Randomized Controlled Clinical Trial. J Dent Res.

CARCUAC, O., DERKS, J., CHARALAMPAKIS, G., ABRAHAMSSON, I., WENNSTROM, J. \& BERGLUNDH, T. 2016. Adjunctive Systemic and Local Antimicrobial Therapy in the Surgical Treatment of Peri-implantitis: A Randomized Controlled Clinical Trial. J Dent Res, 95, 50-7.

CARRAL, C., MUNOZ, F., PERMUY, M., LINARES, A., DARD, M. \& BLANCO, J. 2016. Mechanical and chemical implant decontamination in surgical peri-implantitis treatment: preclinical "in vivo" study. J Clin Periodontol, 43, 694-701.

CHARALAMPAKIS, G., LEONHARDT, A., RABE, P. \& DAHLEN, G. 2012. Clinical and microbiological characteristics of periimplantitis cases: a retrospective multicentre study. Clin Oral Implants Res, 23, 1045-54.

CHRISTIAENS, V., DE BRUYN, H., THEVISSEN, E., KOOLE, S., DIERENS, M. \& COSYN, J. 2018. Assessment of periodontal bone level revisited: a controlled study on the diagnostic accuracy of clinical evaluation methods and intra-oral radiography. Clin Oral Investig, 22, 425-431.

CLAFFEY, N., CLARKE, E., POLYZOIS, I. \& RENVERT, S. 2008. Surgical treatment of peri-implantitis. J Clin Periodontol, 35, 316-32. 
COCHRAN, D. L., NUMMIKOSKI, P. V., SCHOOLFIELD, J. D., JONES, A. A. \& OATES, T. W. 2009. A prospective multicenter 5-year radiographic evaluation of crestal bone levels over time in 596 dental implants placed in 192 patients. J Periodontol, 80, 725-33.

COSTA, F. O., TAKENAKA-MARTINEZ, S., COTA, L. O., FERREIRA, S. D., SILVA, G. L. \& COSTA, J. E. 2012. Periimplant disease in subjects with and without preventive maintenance: a 5-year follow-up. J Clin Periodontol, 39, 17381.

DE MELO, F., DO NASCIMENTO, C., SOUZA, D. O. \& DE ALBUQUERQUE, R. F., JR. 2016. Identification of oral bacteria on titanium implant surfaces by $16 \mathrm{~S}$ rDNA sequencing. Clin Oral Implants Res, 00, 1-7.

DERKS, J. \& TOMASI, C. 2015. Peri-implant health and disease. A systematic review of current epidemiology. Journal of Clinical Periodontology, 42, S158-S171.

ERICSSON, I., BERGLUNDH, T., MARINELLO, C., LILJENBERG, B. \& LINDHE, J. 1992. Long-standing plaque and gingivitis at implants and teeth in the dog. Clin Oral Implants Res, 3, 99-103.

ERICSSON, I. \& LINDHE, J. 1993. Probing depth at implants and teeth. An experimental study in the dog. J Clin Periodontol, 20, 623-7.

FEIL, P. H., GRAUER, J. S., GADBURY-AMYOT, C. C., KULA, K. \& MCCUNNIFF, M. D. 2002. Intentional use of the Hawthorne effect to improve oral hygiene compliance in orthodontic patients. J Dent Educ, 66, 1129-35.

FERREIRA RIBEIRO, C., COGO-MULLER, K., FRANCO, G. C., SILVA-CONCILIO, L. R., SAMPAIO CAMPOS, M., DE MELLO RODE, S. \& CLARO NEVES, A. C. 2016. Initial oral biofilm formation on titanium implants with different surface treatments: An in vivo study. Arch Oral Biol, 69, 3339.

FIGUERO, E., GRAZIANI, F., SANZ, I., HERRERA, D. \& SANZ, M. 2014. Management of peri-implant mucositis and periimplantitis. Periodontol 2000, 66, 255-73.

FLICHY-FERNANDEZ, A. J., ATA-ALI, J., ALEGRE-DOMINGO, T., CANDEL-MARTI, E., ATA-ALI, F., PALACIO, J. R. \& PENARROCHA-DIAGO, M. 2015. The effect of orally administered probiotic Lactobacillus reuteri-containing tablets in peri-implant mucositis: a double-blind randomized controlled trial. J Periodontal Res. 
FULLER, R. 1989. Probiotics in man and animals. J Appl Bacteriol, 66, 365-78.

FURST, M. M., SALVI, G. E., LANG, N. P. \& PERSSON, G. R. 2007. Bacterial colonization immediately after installation on oral titanium implants. Clinical Oral Implants Research, 18, 501-8.

GALOFRE, M., PALAO, D., VICARIO, M., NART, J. \& VIOLANT, D. 2018. Clinical and microbiological evaluation of the effect of Lactobacillus reuteri in the treatment of mucositis and periimplantitis: A triple-blind randomized clinical trial. $J$

Periodontal Res, 00, 1-13.

GERBER, J., WENAWESER, D., HEITZ-MAYFIELD, L., LANG, N. P. \& PERSSON, G. R. 2006. Comparison of bacterial plaque samples from titanium implant and tooth surfaces by different methods. Clin Oral Implants Res, 17, 1-7.

GRAZIANI, F., FIGUERO, E. \& HERRERA, D. 2012. Systematic review of quality of reporting, outcome measurements and methods to study efficacy of preventive and therapeutic approaches to peri-implant diseases. J Clin Periodontol, 39 Suppl 12, 224-44.

HAAS, A. N., DE CASTRO, G. D., MORENO, T., SUSIN, C., ALBANDAR, J. M., OPPERMANN, R. V. \& ROSING, C. K. 2008. Azithromycin as an adjunctive treatment of aggressive periodontitis: 12-months randomized clinical trial. J Clin Periodontol, 35, 696-704.

HALLSTROM, H., LINDGREN, S. \& TWETMAN, S. 2017. Effect of a chlorhexidine-containing brush-on gel on peri-implant mucositis. Int J Dent Hyg, 15, 149-53.

HALLSTROM, H., LINDGREN, S., WIDEN, C., RENVERT, S. \& TWETMAN, S. 2015b. Probiotic supplements and debridement of peri-implant mucositis: A randomized controlled trial. Acta Odontol Scand, 1-7.

HALLSTROM, H., PERSSON, G. R., STROMBERG, U., TWETMAN, S. \& RENVERT, S. 2015c. Reproducibility of subgingival bacterial samples from patients with peri-implant mucositis. Clin Oral Investig, 19, 1063-8.

HEITZ-MAYFIELD, L. J., SALVI, G. E., BOTTICELLI, D., MOMBELLI, A., FADDY, M. \& LANG, N. P. 2011. Antiinfective treatment of peri-implant mucositis: a randomised controlled clinical trial. Clin Oral Implants Res, 22, 237-41. 
HEITZ-MAYFIELD, L. J., SALVI, G. E., MOMBELLI, A., FADDY, M. \& LANG, N. P. 2012. Anti-infective surgical therapy of peri-implantitis. A 12-month prospective clinical study. Clin Oral Implants Res, 23, 205-10.

HENTENAAR, D. F. M., DE WAAL, Y. C. M., STROOKER, H., MEIJER, H. J. A., VAN WINKELHOFF, A. J. \&

RAGHOEBAR, G. M. 2017. Implant decontamination with phosphoric acid during surgical peri-implantitis treatment: a RCT. Int J Implant Dent, 3, 33.

HJALMARSSON, L., GHEISARIFAR, M. \& JEMT, T. 2016. A systematic review of survival of single implants as presented in longitudinal studies with a follow-up of at least 10 years. Eur J Oral Implantol, 9 Suppl 1, S155-62.

INIESTA, M., HERRERA, D., MONTERO, E., ZURBRIGGEN, M., MATOS, A. R., MARIN, M. J., SANCHEZ-BELTRAN, M. C., LLAMA-PALACIO, A. \& SANZ, M. 2012. Probiotic effects of orally administered Lactobacillus reuteri-containing tablets on the subgingival and salivary microbiota in patients with gingivitis. A randomized clinical trial. J Clin Periodontol, 39, 736-44.

IWAMOTO, T., SUZUKI, N., TANABE, K., TAKESHITA, T. \& HIROFUJI, T. 2010. Effects of probiotic Lactobacillus salivarius WB21 on halitosis and oral health: an open-label pilot trial. Oral Surg Oral Med Oral Pathol Oral Radiol Endod, 110, 201-8.

JEPSEN, S., BERGLUNDH, T., GENCO, R., AASS, A. M., DEMIREL, K., DERKS, J., FIGUERO, E., GIOVANNOLI, J. L., GOLDSTEIN, M., LAMBERT, F., ORTIZ-VIGON, A., POLYZOIS, I., SALVI, G. E., SCHWARZ, F., SERINO, G., TOMASI, C. \& ZITZMANN, N. U. 2015a. Primary prevention of peri-implantitis: managing peri-implant mucositis. J Clin Periodontol, 42 Suppl 16, S152-7.

KILIAN, M., CHAPPLE, I. L., HANNIG, M., MARSH, P. D., MEURIC, V., PEDERSEN, A. M., TONETTI, M. S., WADE, W. G. \& ZAURA, E. 2016. The oral microbiome - an update for oral healthcare professionals. $\mathrm{Br}$ Dent J, 221, 657-666.

KRASSE, P., CARLSSON, B., DAHL, C., PAULSSON, A., NILSSON, A. \& SINKIEWICZ, G. 2006. Decreased gum bleeding and reduced gingivitis by the probiotic Lactobacillus reuteri. Swed Dent J, 30, 55-60. 
KUMAR, P. S., MASON, M. R., BROOKER, M. R. \& O'BRIEN, K. 2012. Pyrosequencing reveals unique microbial signatures associated with healthy and failing dental implants. J Clin Periodontol, 39, 425-33.

LAI, P. C., HO, W., JAIN, N. \& WALTERS, J. D. 2011. Azithromycin concentrations in blood and gingival crevicular fluid after systemic administration. J Periodontol, 82, 1582-6.

LANG, N. P. \& BERGLUNDH, T. 2011. Periimplant diseases: where are we now?--Consensus of the Seventh European Workshop on Periodontology. J Clin Periodontol, 38 Suppl 11, 178-81.

LANG, N. P., WETZEL, A. C., STICH, H. \& CAFFESSE, R. G. 1994. Histologic probe penetration in healthy and inflamed periimplant tissues. Clin Oral Implants Res, 5, 191-201.

LARSEN, T. 2002. Susceptibility of Porphyromonas gingivalis in biofilms to amoxicillin, doxycycline and metronidazole. Oral Microbiol Immunol, 17, 267-71.

LAURELL, L. \& LUNDGREN, D. 2011. Marginal bone level changes at dental implants after 5 years in function: a meta-analysis. Clin Implant Dent Relat Res, 13, 19-28.

LAVDA, M., CLAUSNITZER, C. E. \& WALTERS, J. D. 2004. Distribution of systemic ciprofloxacin and doxycycline to gingiva and gingival crevicular fluid. J Periodontol, 75, 16637.

LAXMINARAYAN, R., DUSE, A., WATTAL, C., ZAIDI, A. K., WERTHEIM, H. F., SUMPRADIT, N., VLIEGHE, E., HARA, G. L., GOULD, I. M., GOOSSENS, H., GREKO, C., SO, A. D., BIGDELI, M., TOMSON, G., WOODHOUSE, W., OMBAKA, E., PERALTA, A. Q., QAMAR, F. N., MIR, F., KARIUKI, S., BHUTTA, Z. A., COATES, A., BERGSTROM, R., WRIGHT, G. D., BROWN, E. D. \& CARS, O. 2013. Antibiotic resistance-the need for global solutions. Lancet Infect Dis, 13, 1057-98.

LEONHARDT, A., DAHLEN, G. \& RENVERT, S. 2003. Five-year clinical, microbiological, and radiological outcome following treatment of peri-implantitis in man. J Periodontol, 74, 141522.

LINDHE, J., MEYLE, J. \& GROUP, D. O. E. W. O. P. 2008. Periimplant diseases: Consensus Report of the Sixth European Workshop on Periodontology. J Clin Periodontol, 35, 282-5. 
LINDQUIST, L. W., ROCKLER, B. \& CARLSSON, G. E. 1988. Bone resorption around fixtures in edentulous patients treated with mandibular fixed tissue-integrated prostheses. J Prosthet Dent, 59, 59-63.

LOE, H., THEILADE, E. \& JENSEN, S. B. 1965. EXPERIMENTAL GINGIVITIS IN MAN. J Periodontol, 36, 177-87.

MAEKAWA, T. \& HAJISHENGALLIS, G. 2014. Topical treatment with probiotic Lactobacillus brevis CD2 inhibits experimental periodontal inflammation and bone loss. J Periodontal Res, $49,785-91$.

MARCOTTE, H., KOLL-KLAIS, P., HULTBERG, A., ZHAO, Y., GMUR, R., MANDAR, R., MIKELSAAR, M. \& HAMMARSTROM, L. 2006. Expression of single-chain antibody against RgpA protease of Porphyromonas gingivalis in Lactobacillus. J Appl Microbiol, 100, 256-63.

MARTIN-CABEZAS, R., DAVIDEAU, J. L., TENENBAUM, H. \& HUCK, O. 2016. Clinical efficacy of probiotics as an adjunctive therapy to non-surgical periodontal treatment of chronic periodontitis: a systematic review and meta-analysis. $J$ Clin Periodontol, 43, 520-30.

MASCARENHAS, P., GAPSKI, R., AL-SHAMMARI, K., HILL, R., SOEHREN, S., FENNO, J. C., GIANNOBILE, W. V. \& WANG, H. L. 2005. Clinical response of azithromycin as an adjunct to non-surgical periodontal therapy in smokers. $J$ Periodontol, 76, 426-36.

MAXIMO, M. B., DE MENDONCA, A. C., RENATA SANTOS, V., FIGUEIREDO, L. C., FERES, M. \& DUARTE, P. M. 2009. Short-term clinical and microbiological evaluations of periimplant diseases before and after mechanical anti-infective therapies. Clinical Oral Implants Research, 20, 99-108.

MAYANAGI, G., KIMURA, M., NAKAYA, S., HIRATA, H., SAKAMOTO, M., BENNO, Y. \& SHIMAUCHI, H. 2009. Probiotic effects of orally administered Lactobacillus salivarius WB21-containing tablets on periodontopathic bacteria: a double-blinded, placebo-controlled, randomized clinical trial. J Clin Periodontol, 36, 506-13.

METCHNIKOFF, E. 1907. The prolongation of life: Optimistic studies. London: William Heinemann.

MOMBELLI, A., BUSER, D. \& LANG, N. P. 1988. Colonization of osseointegrated titanium implants in edentulous patients. Early results. Oral Microbiol Immunol, 3, 113-20. 
MOMBELLI, A. \& DECAILLET, F. 2011. The characteristics of biofilms in peri-implant disease. J Clin Periodontol, 38 Suppl 11, 203-13.

MOMBELLI, A., FELOUTZIS, A., BRAGGER, U. \& LANG, N. P. 2001. Treatment of peri-implantitis by local delivery of tetracycline. Clinical, microbiological and radiological results. Clin Oral Implants Res, 12, 287-94.

MOMBELLI, A., MULLER, N. \& CIONCA, N. 2012. The epidemiology of peri-implantitis. Clinical Oral Implants Research, 23 Suppl 6, 67-76.

MOMBELl, A., VAN OOSTEN, M. A., SCHURCH, E., JR. \& LAND, N. P. 1987. The microbiota associated with successful or failing osseointegrated titanium implants. Oral Microbiol Immunol, 2, 145-51.

MONCLA, B. J., BRAHAM, P. H., PERSSON, G. R., PAGE, R. C. \& WEINBERG, A. 1994. Direct detection of Porphyromonas gingivalis in Macaca fascicularis dental plaque samples using an oligonucleotide probe. J Periodontol, 65, 398-403.

MONGARDINI, C., PILLONI, A., FARINA, R., TANNA, G. D. \& ZEZA, B. 2017. Adjunctive efficacy of probiotics in the treatment of experimental peri-implant-mucositis with mechanical and photodynamic therapy: a randomized, crossover clinical trial. J Clin Periodontol, 44, 410-7.

MONTERO, E., INIESTA, M., RODRIGO, M., MARIN, M. J., FIGUERO, E., HERRERA, D. \& SANZ, M. 2017. Clinical and microbiological effects of the adjunctive use of probiotics in the treatment of gingivitis: A randomized controlled clinical trial. J Clin Periodontol, 44, 708-716.

OETTINGER-BARAK, O., DASHPER, S. G., CATMULL, D. V., ADAMS, G. G., SELA, M. N., MACHTEI, E. E. \& REYNOLDS, E. C. 2013. Antibiotic susceptibility of Aggregatibacter actinomycetemcomitans JP2 in a biofilm. $J$ Oral Microbiol, 5, 20320.

OFFENBACHER, S., BARROS, S., MENDOZA, L., MAURIELLO, S., PREISSER, J., MOSS, K., DE JAGER, M. \& ASPIRAS, M. 2010. Changes in gingival crevicular fluid inflammatory mediator levels during the induction and resolution of experimental gingivitis in humans. J Clin Periodontol, 37, $324-33$.

OWENS, J., ADDY, M. \& FAULKNER, J. 1997. An 18-week homeuse study comparing the oral hygiene and gingival health benefits of triclosan and fluoride toothpastes. J Clin Periodontol, 24, 626-31. 
PAPATHANASIOU, E., FINKELMAN, M., HANLEY, J. \& PARASHIS, A. O. 2016. Prevalence, Etiology and Treatment of Peri-Implant Mucositis and Peri-Implantitis: A Survey of Periodontists in the United States. J Periodontol, 87, 493-501.

PARK, J. H., KIM, Y. S., RYU, J. J., SHIN, S. W. \& LEE, J. Y. 2017. Cumulative survival rate and associated risk factors of Implantium implants: A 10-year retrospective clinical study. $J$ Adv Prosthodont, 9, 195-199.

PARKER, R. B. 1974. Probiotics: the other half of the antibiotic story. Animal Nutrition and Health, December, 4-8.

PASSOS, S. P., GRESSLER MAY, L., FARIA, R., OZCAN, M. \& BOTTINO, M. A. 2013. Implant-abutment gap versus microbial colonization: Clinical significance based on a literature review. J Biomed Mater Res B Appl Biomater, 101, 1321-8.

PERSSON, G. R. \& RENVERT, S. 2014. Cluster of Bacteria Associated with Peri-Implantitis. Clin Implant Dent Relat Res, 16, 783-793.

PERSSON, G. R., ROOS-JANSAKER, A. M., LINDAHL, C. \& RENVERT, S. 2011. Microbiologic results after non-surgical erbium-doped:yttrium, aluminum, and garnet laser or airabrasive treatment of peri-implantitis: a randomized clinical trial. J Periodontol, 82, 1267-78.

PERSSON, G. R., SAMUELSSON, E., LINDAHL, C. \& RENVERT, S. 2010. Mechanical non-surgical treatment of periimplantitis: a single-blinded randomized longitudinal clinical study. II. Microbiological results. J Clin Periodontol, 37, 56373.

PONTORIERO, R., TONELLI, M. P., CARNEVALE, G., MOMBELLI, A., NYMAN, S. R. \& LANG, N. P. 1994. Experimentally induced peri-implant mucositis. A clinical study in humans. Clinical Oral Implants Research, 5, 254-9.

RAGHUNATHA, K. \& GEORGE, J. P. 2013. Periodontal tissue and serum concentration of clarithromycin after systemic administration in patients affected by chronic periodontitis. $J$ Periodontol, 84, e17-22.

RAMANAUSKAITE, A., DAUGELA, P. \& JUODZBALYS, G. 2016. Treatment of peri-implantitis: Meta-analysis of findings in a systematic literature review and novel protocol proposal. Quintessence Int, 47, 379-93. 
RAMBERG, P., LINDHE, J., BOTTICELLI, D. \& BOTTICELLI, A. 2009. The effect of a triclosan dentifrice on mucositis in subjects with dental implants: a six-month clinical study. $J$ Clin Dent, 20, 103-7.

RENVERT, S., LESSEM, J., DAHLEN, G., LINDAHL, C. \& SVENSSON, M. 2006. Topical minocycline microspheres versus topical chlorhexidine gel as an adjunct to mechanical debridement of incipient peri-implant infections: a randomized clinical trial. J Clin Periodontol, 33, 362-9.

RENVERT, S., POLYZOIS, I. \& CLAFFEY, N. 2012. Surgical therapy for the control of peri-implantitis. Clin Oral Implants Res, 23 Suppl 6, 84-94.

RENVERT, S. \& POLYZOIS, I. N. 2015. Clinical approaches to treat peri-implant mucositis and peri-implantitis. Periodontol 2000, 68, 369-404.

RENVERT, S., ROOS-JANSAKER, A.-M. \& CLAFFEY, N. 2008. Non-surgical treatment of peri-implant mucositis and periimplantitis: a literature review. J Clin Periodontol, 35, 305-15.

RENVERT, S., ROOS-JANSAKER, A.-M., LINDAHL, C., RENVERT, H. \& RUTGER PERSSON, G. 2007. Infection at titanium implants with or without a clinical diagnosis of inflammation. Clin Oral Implants Res, 18, 509-16.

RENVERT, S., SAMUELSSON, E., LINDAHL, C. \& PERSSON, G. R. 2009. Mechanical non-surgical treatment of periimplantitis: a double-blind randomized longitudinal clinical study. I: clinical results. J Clin Periodontol, 36, 604-9.

RENVERT, S., WIDEN, C. \& PERSSON, R. G. 2016. Cytokine and microbial profiles in relation to the clinical outcome following treatment of peri-implantitis. Clin Oral Implants Res.

ROCCUZZO, M., BONINO, F., BONINO, L. \& DALMASSO, P. 2011. Surgical therapy of peri-implantitis lesions by means of a bovine-derived xenograft: comparative results of a prospective study on two different implant surfaces. J Clin Periodontol, 38, 738-45.

ROMEO, E., GHISOLFI, M., MURGOLO, N., CHIAPASCO, M., LOPS, D. \& VOGEL, G. 2005. Therapy of peri-implantitis with resective surgery. A 3-year clinical trial on rough screwshaped oral implants. Part I: clinical outcome. Clin Oral Implants Res, 16, 9-18. 
ROOS-JANSAKER, A.-M., RENVERT, H., LINDAHL, C. \& RENVERT, S. 2007. Surgical treatment of peri-implantitis using a bone substitute with or without a resorbable membrane: a prospective cohort study. J Clin Periodontol, 34, 625-32.

ROOS-JANSAKER, A. M., ALMHOJD, U. S. \& JANSSON, H. 2017. Treatment of peri-implantitis: clinical outcome of chloramine as an adjunctive to non-surgical therapy, a randomized clinical trial. Clin Oral Implants Res, 28,43-8.

ROOS-JANSAKER, A. M., LINDAHL, C., PERSSON, G. R. \& RENVERT, S. 2011. Long-term stability of surgical bone regenerative procedures of peri-implantitis lesions in a prospective case-control study over 3 years. J Clin Periodontol, 38, 590-7.

ROOS-JANSAKER, A. M., PERSSON, G. R., LINDAHL, C. \& RENVERT, S. 2014. Surgical treatment of peri-implantitis using a bone substitute with or without a resorbable membrane: a 5-year follow-up. J Clin Periodontol, 41, 110814.

SAIER, M. H., JR. \& MANSOUR, N. M. 2005. Probiotics and prebiotics in human health. J Mol Microbiol Biotechnol, 10, 22-5.

SALVI, G. E., AGLIETTA, M., EICK, S., SCULEAN, A., LANG, N. P. \& RAMSEIER, C. A. 2012. Reversibility of experimental peri-implant mucositis compared with experimental gingivitis in humans. Clin Oral Implants Res, 23, 182-90.

SANZ, M. \& CHAPPLE, I. L. 2012. Clinical research on peri-implant diseases: consensus report of Working Group 4. J Clin Periodontol, 39 Suppl 12, 202-6.

SCHOU, S., BERGLUNDH, T. \& LANG, N. P. 2004. Surgical treatment of peri-implantitis. Int J Oral Maxillofac Implants, 19 Suppl, 140-9.

SCHOU, S., HOLMSTRUP, P., STOLTZE, K., HJORTINGHANSEN, E., FIEHN, N. E. \& SKOVGAARD, L. T. 2002. Probing around implants and teeth with healthy or inflamed peri-implant mucosa/gingiva. A histologic comparison in cynomolgus monkeys (Macaca fascicularis). Clinical Oral Implants Research, 13, 113-26.

SCHWARZ, F., BECKER, K. \& SAGER, M. 2015a. Efficacy of professionally administered plaque removal with or without adjunctive measures for the treatment of peri-implant mucositis. A systematic review and meta-analysis. Journal of Clinical Periodontology, 42, S202-S213. 
SCHWARZ, F., HEGEWALD, A., JOHN, G., SAHM, N. \& BECKER, J. 2013. Four-year follow-up of combined surgical therapy of advanced peri-implantitis evaluating two methods of surface decontamination. J Clin Periodontol, 40, 962-7.

SCHWARZ, F., SCHMUCKER, A. \& BECKER, J. 2015b. Efficacy of alternative or adjunctive measures to conventional treatment of peri-implant mucositis and peri-implantitis: a systematic review and meta-analysis. Int J Implant Dent, 1, 22.

SERINO, G., SATO, H., HOLMES, P. \& TURRI, A. 2017. Intrasurgical vs. radiographic bone level assessments in measuring peri-implant bone loss. Clin Oral Implants Res, 28, 13961400.

SERINO, G. \& STROM, C. 2009. Peri-implantitis in partially edentulous patients: association with inadequate plaque control. Clin Oral Implants Res, 20, 169-74.

SERINO, G. \& TURRI, A. 2011. Outcome of surgical treatment of peri-implantitis: results from a 2-year prospective clinical study in humans. Clin Oral Implants Res, 22, 1214-20.

SHIMAUCHI, H., MAYANAGI, G., NAKAYA, S., MINAMIBUCHI, M., ITO, Y., YAMAKI, K. \& HIRATA, H. 2008. Improvement of periodontal condition by probiotics with Lactobacillus salivarius WB21: a randomized, double-blind, placebo-controlled study. J Clin Periodontol, 35, 897-905.

SINKIEWICZ, G., CRONHOLM, S., LJUNGGREN, L., DAHLEN, G. \& BRATTHALL, G. 2010. Influence of dietary supplementation with Lactobacillus reuteri on the oral flora of healthy subjects. Swed Dent J, 34, 197-206.

SJÖDIN, L. 2015. Ett tandvårdsstöd för alla - fler och starkare patienter. Bilaga 2. Statens Offentliga Utredningar 2015/76.

SMITH, S. R., FOYLE, D. M., DANIELS, J., JOYSTON-BECHAL, S., SMALES, F. C., SEFTON, A. \& WILLIAMS, J. 2002. A double-blind placebo-controlled trial of azithromycin as an adjunct to non-surgical treatment of periodontitis in adults: clinical results. J Clin Periodontol, 29, 54-61.

SOCRANSKY, S. S., HAFFAJEE, A. D., SMITH, C., MARTIN, L., HAFFAJEE, J. A., UZEL, N. G. \& GOODSON, J. M. 2004. Use of checkerboard DNA-DNA hybridization to study complex microbial ecosystems. Oral Microbiol Immunol, 19, 352-62.

STAAB, B., EICK, S., KNOFLER, G. \& JENTSCH, H. 2009. The influence of a probiotic milk drink on the development of gingivitis: a pilot study. J Clin Periodontol, 36, 850-6. 
STAMATOVA, I. \& MEURMAN, J. H. 2009. Probiotics and periodontal disease. Periodontol 2000, 51, 141-51.

TADA, H., MASAKI, C., TSUKA, S., MUKAIBO, T., KONDO, Y. \& HOSOKAWA, R. 2017. The effects of Lactobacillus reuteri probiotics combined with azithromycin on peri-implantitis: A randomized placebo-controlled study. J Prosthodont Res.

TEUGHELS, W., LOOZEN, G. \& QUIRYNEN, M. 2011. Do probiotics offer opportunities to manipulate the periodontal oral microbiota? J Clin Periodontol, 38 Suppl 11, 159-77.

TEUGHELS, W., VAN ESSCHE, M., SLIEPEN, I. \& QUIRYNEN, M. 2008. Probiotics and oral healthcare. Periodontology 2000, 48, 111-47.

THONE-MUHLING, M., SWIERKOT, K., NONNENMACHER, C., MUTTERS, R., FLORES-DE-JACOBY, L. \& MENGEL, R. 2010. Comparison of two full-mouth approaches in the treatment of peri-implant mucositis: a pilot study. Clinical Oral Implants Research, 21, 504-12.

TONETTI, M. S., CHAPPLE, I. L. C., JEPSEN, S. \& SANZ, M. 2015. Primary and secondary prevention of periodontal and periimplant diseases. Journal of Clinical Periodontology, 42, S1S4.

TROMBELLI, L., FARINA, R., MINENNA, L., CARRIERI, A., SCAPOLI, C. \& TATAKIS, D. N. 2008. Experimental gingivitis: reproducibility of plaque accumulation and gingival inflammation parameters in selected populations during a repeat trial. J Clin Periodontol, 35, 955-60.

TROMBELLI, L., SCAPOLI, C., CALURA, G. \& TATAKIS, D. N. 2006. Time as a factor in the identification of subjects with different susceptibility to plaque-induced gingivitis. J Clin Periodontol, 33, 324-8.

TROMBELLI, L., SCAPOLI, C., ORLANDINI, E., TOSI, M., BOTTEGA, S. \& TATAKIS, D. N. 2004. Modulation of clinical expression of plaque-induced gingivitis. III. Response of "high responders" and "low responders" to therapy. J Clin Periodontol, 31, 253-9.

TWETMAN, S., DERAWI, B., KELLER, M., EKSTRAND, K., YUCEL-LINDBERG, T. \& STECKSEN-BLICKS, C. 2009. Short-term effect of chewing gums containing probiotic Lactobacillus reuteri on the levels of inflammatory mediators in gingival crevicular fluid. Acta Odontol Scand, 67, 19-24. 
VAN VELZEN, F. J., OFEC, R., SCHULTEN, E. A. \& TEN

BRUGGENKATE, C. M. 2015. 10-year survival rate and the incidence of peri-implant disease of 374 titanium dental implants with a SLA surface: a prospective cohort study in 177 fully and partially edentulous patients. Clin Oral Implants Res, 26, 1121-8.

VILLARINHO, E. A., CORREIA, A., VIGO, A., RAMOS, N. V., PIRES VAZ, M. A. \& ARAI SHINKAI, R. S. 2018.

Volumetric Bone Measurement Around Dental Implants Using 3D Image Superimposition: A Methodological and Clinical Pilot Study. Int J Prosthodont, 31, 23-30.

VIVEKANANDA, M. R., VANDANA, K. L. \& BHAT, K. G. 2010. Effect of the probiotic Lactobacilli reuteri (Prodentis) in the management of periodontal disease: a preliminary randomized clinical trial. J Oral Microbiol, 2.

WANG, H. L., GARAICOA-PAZMINO, C., COLLINS, A., ONG, H. S., CHUDRI, R. \& GIANNOBILE, W. V. 2016a. Protein biomarkers and microbial profiles in peri-implantitis. Clin Oral Implants Res, 27, 1129-36.

WANG, Y., ZHANG, Y. \& MIRON, R. J. 2016b. Health, Maintenance, and Recovery of Soft Tissues around Implants. Clin Implant Dent Relat Res, 18, 618-34.

WHO Food and Agriculture Organization and World Health Organisation Expert Consultation. Evaluation of health and nutritional properties of powder milk and live lactic acid bacteria. 2001

WHO. (2002) Guidelines for the evaluation ofv probiotic food. London, ON, Canada. Available at http://www.who/int/foodsafety/fs_ management/en/probiotic_guidelines.pdf (accessed April 30 and May 1, 2000).

YANINE, N., ARAYA, I., BRIGNARDELLO-PETERSEN, R., CARRASCO-LABRA, A., GONZALEZ, A., PRECIADO, A., VILLANUEVA, J., SANZ, M. \& MARTIN, C. 2013. Effects of probiotics in periodontal diseases: a systematic review. Clin Oral Investig, 17, 1627-34.

YASHIMA, A., GOMI, K., MAEDA, N. \& ARAI, T. 2009. One-stage full-mouth versus partial-mouth scaling and root planing during the effective half-life of systemically administered azithromycin. J Periodontol, 80, 1406-13. 
ZITZMANN, N. U. \& BERGLUNDH, T. 2008. Definition and prevalence of peri-implant diseases. Journal of Clinical Periodontology, 35, 286-91.

ZITZMANN, N. U., BERGLUNDH, T., MARINELLO, C. P. \& LINDHE, J. 2001. Experimental peri-implant mucositis in man. Journal of Clinical Periodontology, 28, 517-23. 


ISBN 978-9I-7 IO4-904-9 (print)

ISBN 978-9I-7IO4-905-6 (pdf)

MALMÖ UNIVERSITY 20506 MALMÖ, SWEDEN WWW.MAU.SE 